\title{
DETERMINANTS OF THE
}

\section{FEDERAL FUNDS RATE: 1979-1982}

\author{
Timothy Cook*
}

In the late 1970 s the money stock was growing at a faster rate than desired, the rate of inflation was accelerating, and the dollar was steadily depreciating in the foreign exchange markets. In an attempt to reverse these developments the Federal Reserve on October 6, 1979 announced several actions, including a change in its operating procedures to place more emphasis on managing the growth of bank reserves in order to improve monetary control. ${ }^{1}$ The new procedures are generally thought to have remained in place until October 9, 1982, when Federal Reserve Chairman Paul Volcker announced that the Fed was going to temporarily place less emphasis on the money stock (M1) in its policy decisions. The period between October 1979 and October 1982 was characterized by unusually high and volatile shortterm interest rates, volatile money growth rates, and-towards the end of the period-a sharp drop in the rate of inflation. Many accounts of this period have attributed these developments to the new procedures.

The issue addressed in this paper is how the Fed's operating procedures actually changed in October 1979 and, more specifically, how movements in the federal funds rate were determined. ${ }^{2}$ Before October 1979, the Federal Open Market Committee (FOMC) at each meeting set an initial target for the funds rate and gave a set of instructions to the Account Manager at the Federal Reserve Bank of New York (the

\footnotetext{
- Marvin Goodfriend provided many helpful suggestions on this paper. The author also benefited from comments by Dan Bechter, Alfred Broaddus, Robert Hetzel, and Thomas Humphrey. The views expressed are those of the author and not necessarily those of the Federal Reserve Bank of Richmond or the Federal Reserve System.

1 For an account of the developments leading up to the change in operating procedures, see "Fed Takes Strong Steps to Restrain Inflation, Shifts Monetary Tactic," The Wall Street Journal, October 8, 1979, p. 1.
}

2 The federal funds rate is the rate on overnight loans of reserves between depository institutions. Changes in the funds rate are important because they generally lead to changes in other shortterm interest rates.
"Desk") on how to adjust the funds rate over the period until the next FOMC meeting. These instructions related desired movements in the funds rate to the projected growth rates of $\mathrm{M} 1$ and $\mathrm{M} 2$ (relative to the short-run tolerance ranges specified by the FOMC) and to other factors such as inflation, economic activity and the behavior of the dollar in the foreign exchange markets. Each week the Desk reset the target for the funds rate based on the behavior of these variables and the latest instructions it had received from the FOMC.

The Fed stopped setting explicit targets for the funds rate after October 6,1979, and a widely held view is that funds rate movements over the following three years were determined by market forces rather than by the Fed. ${ }^{3}$ According to this view, the critical aspect of the new procedures was that the Fed fixed the supply of nonborrowed reserves available to depository institutions so that increases in the money stock and hence in the demand for required reserves would automatically cause increases in the funds rate and other short-term rates. (The mechanism by which this occurred is described below.)

Despite the widespread emphasis on the automatic adjustment in descriptions of the post-October 1979 operating procedures, it was well-recognized at the time that movements in the funds rate under the procedures could also result from purely judgmental actions of the Federal Reserve. These actions included (1) judgmental adjustments to the supply of nonborrowed reserves in the period between FOMC meetings, (2) judgmental adjustments initiated at an FOMC meeting, (3) changes in the discount rate, and (4) changes in the surcharge that at

\footnotetext{
3 For example, see Stigum [1983, p. 369]: "At that time, the Fed decreed that the rate at which funds traded would be wherever market forces took it, which turned out to be all over the lot;" and Morris [1983, p.5]: "The new policy regime initiated in October 1979 was unique, not in that we established money growth targets, but that we sought to achieve them by managing the rate of growth of bank reserves, allowing shortterm rates to be largely market determined."
} 
times during the period was added to the basic discount rate and applied to large banks. ${ }^{4}$

This paper evaluates whether funds rate movements from October 1979 to October 1982 were determined by market forces interacting with a nonborrowed reserve rule or largely on a judgmental basis by the Federal Reserve as in other periods. To make this evaluation, the paper presents a detailed breakdown and analysis of the policy actions affecting the funds rate in this period. I conclude that while some of the movement in the funds rate over this period resulted from the automatic adjustment, most of the movement-roughly two-thirds-was due to judgmental actions of the Fedcral Reserve.

\section{Analytical Framework}

Increases in the federal funds rate in the period from October 1979 through October 1982 came about in two general ways. The first was through an increase in the amount of reserves that banks had to borrow at the discount window (i.e., the amount not supplied by the Fed in the form of nonborrowed reserves), hereafter called the "borrowed reserves target." 5 The demand by banks for borrowed reserves depends positively on the spread between the federal funds rate and the discount rate. Therefore, in general, the larger the amount of reserves banks had to borrow at the discount window, the greater the spread between the funds rate and the discount rate necessary to induce them to borrow these reserves. Consequently, at a given discount rate an increase in the amount of reserves

\footnotetext{
4 It should be emphasized that most Federal Reserve descriptions of the operating procedures in this period did not claim that funds rate movements were being determined solely by the automatic adjustment. Levin and Meek [1981], Volcker [1980], and the New York Federal Reserve Bank's reviews of monetary policy and open market operations [1980, 1981, 1982, 1983] all describe the effects on the funds rate of judgmental adjustments to the supply of nonborrowed reserves and changes in the discount rate and surcharge.

5 The term generally used in this period to denote the initial borrowing level specified by the FOMC for an intermeeting period was the "borrowed reserve assumption." This term was used because-as will be explained later in the article-under the procedures the amount of reserves that banks had to borrow in the period between FOMC meetings depended on the growth rate of money, which was unknown at the beginning of the period. Hence, the initial borrowing level changed as the period developed. The borrowing level specified for a particular week within the intermeeting period was in effect a target because under the prevailing system of lagged reserve requirements a target for nonborrowed reserves implied a specific level of borrowed reserves. To simplify the discussion and the presentation of the data, I use "target" for both purposes. As will be clear in the text, the use of that term is not meant to suggest that the borrowing level initially specified by the FOMC was fixed throughout the intermeeting period.
}

banks had to borrow resulted in a higher funds rate. Increases in the funds rate in this period also resulted from increases in the basic discount rate or the surcharge. The funds rate had to rise following an increase in the discount rate in order to maintain the spread between the two rates necessary to achieve the borrowed reserve target in the current week.

The approach taken in this paper is to track changes in the borrowed reserve target, the discount rate, and the surcharge from October 1979 to October 1982 and to estimate how much of the resulting movement in the funds rate was attributable to the automatic adjustment and how much to judgmental actions by the Fed. The basic analytical procedure is to construct a series of tables which document the timing and cause of changes in the borrowed reserve target as well as the timing of changes in the discount rate and the surcharge. Table I illustrates the procedure with data for the period beginning after the March 31, 1981 FOMC meeting and ending May 20,1981, the day following the next FOMC meeting. Over this period the funds rate rose 3.96 percentage points. Similar tables for each of the intermeeting periods from October 1979 to October 1982 are in a working paper [Cook, 1989]. (A compact version of these tables is provided in the Appendix.) All information in Table $I$ is from the weekly Report of Open Market Operations prepared by the Federal Reserve Bank of New York. The explanatory notes in the table are direct quotes from the Report.

This section of the paper works through Table II to identify how much of the change in the borrowed reserve target in the intermeeting period ending May 20,1981 resulted from the automatic adjustment and how much resulted from judgmental actions taken by the Federal Reserve. This information is used together with the changes in the discount rate and surcharge documented in Table I to estimate the amount of the change in the funds rate in this intermeeting period resulting from the automatic adjustment and the amount resulting from judgmental actions by the Fed. The following section of the paper provides similar estimates for the full period from October 1979 to October 1982.

The initial borrowed reserve target In the postOctober 1979 period the Federal Open Market Committee at each meeting chose an initial target for borrowed reserves for the period until the subsequent meeting. This target, which was generally called the "borrowed reserve assumption," is shown in column 3 of Table I. As notcd above, the demand by banks to borrow reserves at the discount window largely depends on the spread between the federal 
Table 1

BEHAVIOR OF BORROWED RESERVES, THE DISCOUNT RATE, AND THE FUNDS RATE IN THE INTERMEETING PERIOD ENDING MAY 20, 1981

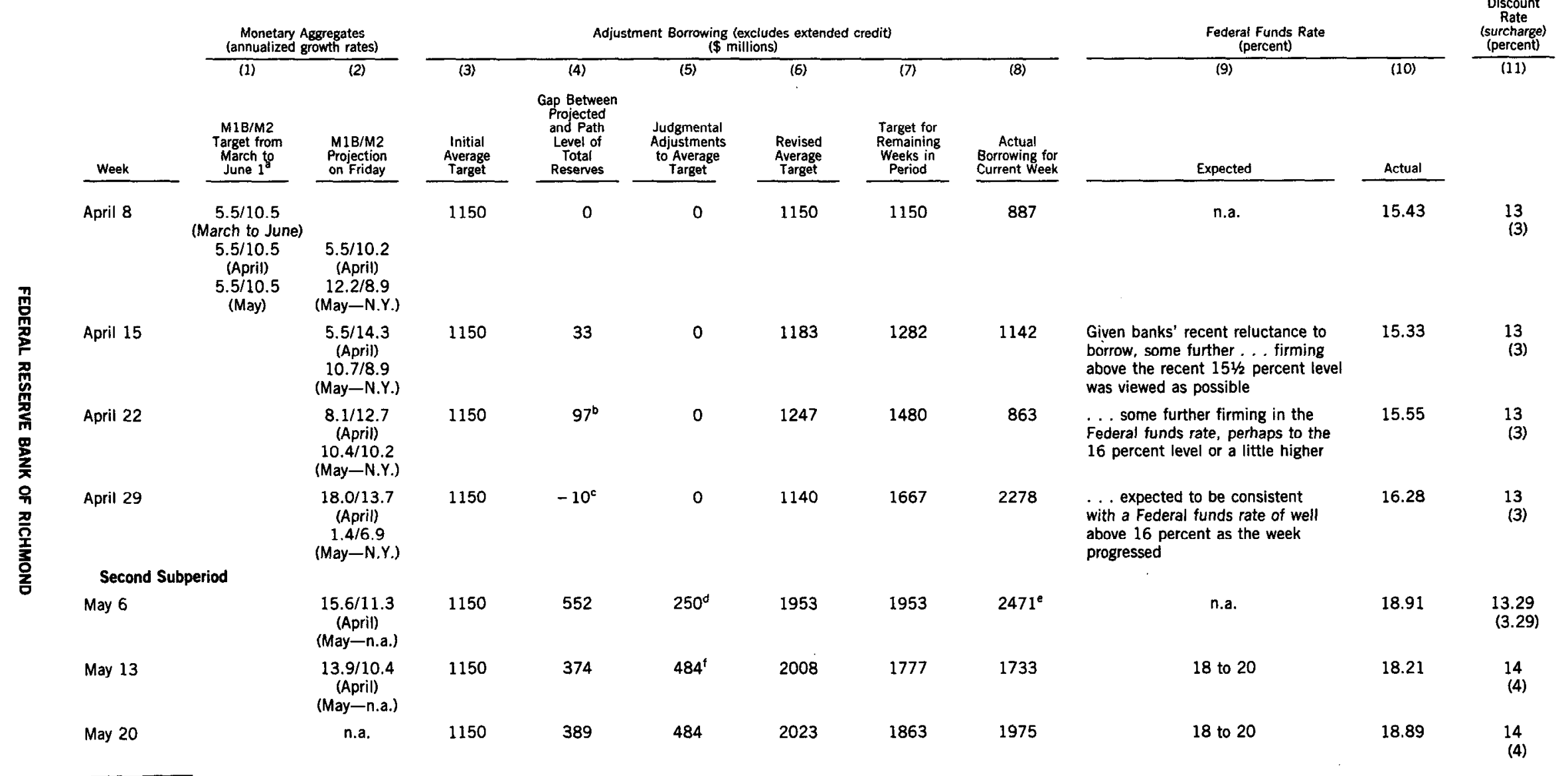

a1B is adjusted for the estimated impact of NOW account shifts.

b A review of technical factors... suggested the potential for modest downward adjustment to the reserve paths. However, given the volatility of the data and the modest size of the suggested changes, no

A review of technical factors. . showed sizable potential downward adjustments to the [total and hence nonborrowed] path. The effect of making these adjustments would have raised the projected borrawing
level $\ldots$ to as high as $\$ 2.8$ billion. in order to smooth the transition between reserve periods... it was decided to leave the reserve paths for the first subperiod unchanged.

d Given the size of this [total reserves] gap, a decision was made, in consultation with the Chairman, to lower the average nonborrowed reserve path relative to the total reserve path by $\$ 250$ million.

e It appeared by midweek that borrowings at the discount window would substantially exceed the level anticipated in the path construction. To have met the nonborrowed reserve objective . . would have tended
to dilute the effects of Monday's discount rate action.

to dilute the effects of Monday's discount rate action.

2) Finally, also in consultation with the Chairman, it was decided to adjust the average nonborrowed reserve path downward because of the $\$ 343$ million undershoot in nonborrowed reserves in the first week of the subperiod ... Consequently,
the average nonborrowed reserve path for the three-week period was lowered by an additional $\$ 114$ million $(\$ 343 \div 3)$. 
funds rate and the discount rate. Hence, in choosing an initial target for borrowed reserves the FOMC was indirectly setting an initial level for the funds rate in the intermeeting period. (Of course, this funds rate level also depended on the prevailing discount rate.) At its March 31, 1981 meeting, the FOMC set an initial target for borrowed reserves for the intermeeting period ending May 20, 1981 of $\$ 1150$ million. This figure was only slightly below the $\$ 1162$ million borrowing target in the last week of the previous intermeeting period.

The automatic adjustment in the borrowed reserve tanget $^{6}$ At each meeting the FOMC also set shortrun targets for $\mathrm{M} 1$ and $\mathrm{M} 2$ over a period of two to four months. These targets are shown in column 1 of Table I, and the most recent projections of money growth are shown in column $2 . .^{7}$ The staff constructed a "path" for total reserves consistent with the money supply targets. In constructing the total reserve path, the staff allowed for the projected mix of currency and deposits and the projected demand by banks for excess reserves, and it took into account the reserve requirements for various categories of deposits. In practice, many of the non-M1 components of M2 were nonreservable and reserves on other components were being phased out under the Monetary Control Act. As a result, the total reserve path was determined primarily by the M1 target.

The staff also constructed a path for nonborrowed reserves by subtracting the FOMC's initial target for borrowed reserves from the total reserve path. The paths for total and nonborrowed reserves were then translated into reserve levels covering the shorter periods between FOMC meetings. The System Account Manager (the "Desk") was instructed to conduct open market operations in the intermeeting period in a manner consistent with achieving the nonborrowed reserve path.

The central feature of the procedures was that as the intermeeting period progressed, the path for

\footnotetext{
6 This brief description of the automatic adjustment is taken primarily from Volcker [1980]. For additional detail see Levin and Meek [1981] and the annual reports on monetary policy and open market operations by the Federal Reserve Bank of New York $[1980,1981,1982,1983]$. Hetzel [1986] provides a chronological review of the implementation of the post-October 1979 procedures, and Goodfriend et al. [1986] provide a weekly rational expectations model of the procedures. Other discussions of the procedures are in Hetzel [1982], Poole [1982], and Spindt and Tarhan [1987].

7 The projections of the monthly growth rates of the monetary aggregates shown in Table $I$ are those made by the staff of the Board of Governors. If projections for a particular month were supplied by the New York staff but not the Board staff, then the New York staff's forecasts are shown in the table.
}

nonborrowed reserves was to be held fixed. If, for example, the projected growth rate of money in the intermeeting period rose above the target set by the FOMC, then the projected level of total reserves would rise above the path level of total reserves. With the nonborrowed reserve path held fixed, the emerging gap between the projected and path levels of total reserves due to the stronger-than-targeted money growth would cause an increase in the amount of reserves that had to be borrowed at the discount window. The funds rate would rise in the current week until the spread between it and the discount rate was large enough to induce banks in the aggregate to borrow these additional rescrves. The result was that stronger-than-targeted money growth would automatically cause a rise in the funds rate, which was supposed to bring money growth back to target over time.

In practice, the Desk made two modifications to the automatic adjustment as described above. First, although the Desk held the average nonborrowed reserve path fixed when there was an increase in the projected demand for total reserves in the intermeeting period, it typically made offsetting adjustments to the weekly nonborrowed reserve path in order to maintain steady borrowing over the remaining weeks of the period (Levin and Meek [1981, pp. 7-8]). Suppose, for example, that in the middle of a six-week intermeeting period new information increased the projected demand for total reserves by an average of $\$ 300$ million over the remaining three weeks of the period, consisting of $\$ 100$ million in week $4, \$ 300$ million in week 5 , and $\$ 500$ million in week 6 . In this situation the Desk would reduce the nonborrowed reserve path by $\$ 200$ million in week 4 , leave it unchanged in week 5 , and raise it by $\$ 200$ million in week 6 . The result would be to raise the borrowed reserve target for each of the remaining three weeks in the period by an equal amount of $\$ 300$ million.

The second modification to the automatic adjustment described above was that the Desk made "technical" adjustments to the paths for total and nonborrowed reserves to allow for changes in the estimates of excess reserves and required reserves against deposits not included in M1 and M2. Suppose, for instance, that in the intermeeting period the demand for total reserves unexpectedly rose by $\$ 50$ million due to an increase in the demand for excess reserves and by $\$ 50$ million due to an increase in required reserves against bank liabilities not included in M1 or M2. If the Desk made no allowance for these factors, the necessary discount-window borrowing by banks would rise by $\$ 100$ million. The 
higher borrowing level would force a rise in the funds rate even though there had been no increase in the projected growth of M1 or M2. To forestall this outcome, the Desk could raise the total and nonborrowed reserve paths by $\$ 100$ million.

In the Report of Open Market Operations, the Desk reported a gap between the projected and path level of total reserves as an average over all the weeks in the intermeeting period. In the above example, where the projected demand for total reserves rose by $\$ 100$ million, $\$ 300$ million, and $\$ 500$ million in the last three weeks of a six-week intermeeting period, the Desk would have raised the gap by $\$ 150$ million $[(100+300+500) / 6]$. The Desk divided fifteen of the twenty-six intermeeting periods into two subperiods, including the period shown in Table I. In these cases the reserve averages were calculated separately for each subperiod.

Column 4 in Table I shows the gap between the average projected and path levels of total reserves for the intermeeting period ending May 20,1981. ${ }^{8}$ As the period developed, the stronger-than-targeted money growth raised the projected level of total reserves. The positive gap between the projected and path levels of total reserves that normally would have resulted from the stronger-than-targeted money growth did not appear at the end of the first subperiod (April 29) because, in order to smooth the transition between the two subperiods, the Desk decided not to make any of the sizable potential downward technical adjustments to the total and nonborrowed reserve paths (note $\mathrm{c}$ in Table I). ${ }^{9}$ These adjust-

\footnotetext{
8 In practice, the initial gap betwecn the projected and path lcvels of total reserves at the time of the FOMC meeting was set equal to zero, although the gap could change in the first week of the intermeeting period if on the Friday following the FOMC meeting (usually on Tuesday) the staff's forecasts for the monetary aggregates differed from those made at the meeting. Setting the initial reserve gap equal to zero did not constrain the FOMC, since if the FOMC wished to engineer a change in the funds rate at the time of the meeting, it could do so by changing the borrowed reserve target from recent borrowing levels.
}

9 The sense in which the transition between the two subperiods was "smoothed" by this decision is as follows. In the first three weeks of the first subperiod, the actual borrowing level (column 8) ran below the borrowing target for the remaining weeks in the subperiod (column 7)-henceforth called the "weekly" target (discussed later in this section). Because of these past misses, the weekly target had to rise steadily as the subperiod progressed in order to achieve the average borrowed reserve target. The Desk did not make any of the downward technical adjustments to the reserve paths at the end of the first subperiod - which would have caused a rise in the revised average and hence weekly borrowed reserve targets-because the weekly target had already risen sharply. If the Desk had made the technical adjustments, the weekly target would have climbed more than it did at the end of the first subperiod and then fallen at the beginning of the second subperiod, rather than rising from ments were made in the second subperiod, however, and in that subperiod the gap between the projected and path levels of total reserves rose sharply. The final gap of $\$ 389$ million for the intermeeting period caused an automatic increase in the average borrowed reserve target of that magnitude.

Judgmental adjustments in the average borrowed reserve target The Desk could also make judgmental adjustments in the average nonborrowed reserve path during the intermeeting period, which would cause offsetting adjustments of the same magnitude in the average borrowed reserve target. The judgmental adjustments in the intermeeting period ending May 20, 1981 are shown in column 5 of Table I, and the Desk's explanations for them are given in the notes at the bottom of the table. In the fifth week of the period (May 6) "given the size of the reserve gap, a decision was made, in consultation with the Chairman," to lower the average nonborrowed reserve path by $\$ 250$ million and thereby raise the average borrowed reserve target by an equal amount (note d). In the sixth week (May 13) it was decided for the same reason to make another judgmental increase in the average borrowed reserve target of $\$ 120$ million (note $\mathrm{f} 1$ ). At the same time, the Desk increased the average borrowed reserve target by an additional $\$ 114$ million "because of the undershoot in nonborrowed reserves" in the previous week (note f2). ${ }^{10}$ The total of $\$ 484$ million of judgmental adjustments over the period more than doubled the increase in the average borrowed reserve target that would have resulted from the automatic adjustment alone. As a result, over the period the average target, shown in column 6 of Table I, rose by a total of $\$ 873$ million from $\$ 1150$ million to $\$ 2023$ million.

the first to the second subperiod as shown in column 7 of - Table I. This example illustrates the operational difficulties in setting targets for average reserve levels.

10 The reasoning behind this adjustment was as follows. The demand for borrowed reserves was stronger than anticipated in the first week of the second subperiod, and the Desk decided to allow borrowing to come in over target (and nonborrowed reserves under target) in order not to dilute the effect on the funds rate of the increase in the discount rate that week (note $\mathrm{e}$ in Table I). In order to accommodate this miss in the borrowed reserve target, the next week the Desk raised the average borrowed reserve target for the subperiod by $\$ 114$ million. If the Desk had not made this adjustment, the weekly borrowing target and the expected funds rate would have been lower in the last two weeks of the subperiod. The Desk occasionally made this type of adjustment to prevent misses in the weekly borrowed reserve target early in an intermeeting period or subperiod from unduly affecting the weekly target later in the period. This type of adjustment is discussed in more detail later in the article (pp. 13-14). 


\section{Determination of the weekly borrowed reserve target} Column 7 in Table I shows the borrowed reserve target for the current and remaining weeks in the period (henceforth called the "weekly target"). This target, together with the discount rate, determined the expected funds rate in the current week. Changes in the weekly borrowed reserve target resulted from changes in the projected demand for total reserves over the period and from deviations of actual borrowing from target in the previous weeks of the period. To understand the calculation of the weekly target, it is useful to work through a week in Table $I$ in detail. Consider the third week of the first subperiod (April 22), when the borrowed reserve target for the remaining two weeks in the subperiod rose by $\$ 198$ million from $\$ 1282$ million to $\$ 1480$ million. Column 4 shows that in this week the average gap over the subperiod between the projected demand for total reserves and the path level rose from $\$ 33$ million to $\$ 97$ million. As explained above, this meant that there was an increase in the cumulative projected demand for total reserves over the fourweek subperiod of $\$ 256$ million [ $(97-33) \times 4]$. With a fixed nonborrowed reserve path, the borrowed reserve target over the remaining two weeks in the subperiod had to go up by $\$ 128$ million (256/2) to supply these additional reserves. The borrowed reserve target for the remaining weeks in the subperiod also had to offset the deviation of $\$ 140$ million between the borrowed reserve target and the actual level of borrowing in the second week of the subperiod (1282 - 1142). With a fixed nonborrowed reserve path, the borrowed reserve target in the remaining two weeks had to rise by $\$ 70$ million $(140 / 2)$ to offset this miss. Together, the increase in the projected demand for total reserves and the miss in the target the second week caused a rise in the target for the third and fourth weeks of $\$ 198$ million $(128+70)$ to $\$ 1480$ million.

The borrowed reserve target for the current and remaining weeks in a period can also be calculated in Table I directly from the average borrowed reserve target and the actual level of borrowing in the previous weeks in the period. The average target in the third week of the first subperiod was $\$ 1247$ million $(1150+97)$. Given borrowing of $\$ 887$ million and $\$ 1142$ million in the first and second weeks of the subperiod (shown in column 8 ), the implied borrowing target for the two remaining weeks was $\$ 1480$ million [(1247 $\times 4-887-1142) / 2]$, which - as derived above - was up $\$ 198$ million from the previous week's target of $\$ 1282$ million. Over the whole intermeeting period ending May 20, 1981, the rise in the average borrowed reserve target of $\$ 873$ million ( 2023 - 1150 ) led to a total rise in the weekly target of $\$ 713$ million (1863 - 1150).

The discount rate and surcharge Increases in the discount rate were an important determinant of the funds rate in the October 1979 to October 1982 period. As indicated earlier, the funds rate had to rise following an increase in the discount rate in order to maintain whatever spread was necessary to achieve the borrowed reserve target in the current week. ${ }^{11}$ On two occasions during the period from October 1979 to October 1982 a surcharge was added to the basic discount rate and applied to banks with deposits over $\$ 500$ million that borrowed for two consecutive weeks or for more than four weeks in a calendar quarter. (After October 1, 1981 the calendar quarter was changed to a moving 13-week period.) Increases in the surcharge also put upward pressure on the funds rate, although the effect was smaller than for increases in the basic discount rate because only large banks were subject to the surcharge (Sellon and Seibert [1982, pp. 9-12]).

As shown in column 11 of Table $I$, in the intermeeting period ending May 20, 1981 there was a one percentage point increase in both the discount rate and the surcharge. The discount rate and the surcharge together with the weekly borrowed reserve target were used by the Desk to derive an expected federal funds rate for the week, shown in column 9. The actual level of borrowed reserves and the actual funds rate for the week are shown in columns 8 and 10.

Determination of the funds rate In summary, in the intermeeting period ending May 20, 1981 the funds rate was pushed up by the automatic adjustment in the borrowed reserve target resulting from the positive gap between the projected and path levels of total reserves, by judgmental adjustments to the borrowed reserve target, and by increases in the discount rate and the surcharge. The effect of each of these factors on the funds rate depends on the characteristics of the demand function for borrowed reserves. Empirical work indicates that a $\$ 100$ million increase in borrowed reserves in this period was associated with an increase in the spread between the funds rate and the discount rate of roughly 25

11 For discussions of the relationship between the funds rate and the discount rate under the October 1979 operating procedures, see Broaddus and Cook [1983] and Sellon and Seibert [1982]. 
basis points. ${ }^{12}$ (The Fed has long used this estimate in relating borrowing levels to the spread.) Using this relationship one can estimate that the $\$ 713$ million increase in the weekly borrowed reserve target over this period raised the funds rate by 178 basis points. Forty-five percent of the increase in the weekly borrowed reserve target was due to the automatic adjustment in the average borrowed reserve target $(389 / 873)$, and 55 percent was due to judgmental adjustments in the average borrowed reserve target (484/873). Hence, one can estimate that the automatic adjustment raised the funds rate by 79 basis points, while the judgmental adjustments raised it by 99 basis points. The small $\$ 13$ million reduction in the borrowed reserve target made at the beginning of the period by the FOMC lowered the funds rate by 3 basis points.

As discussed above, under the October 1979 procedures a one percentage point increase in the discount rate would be expected to raise the funds rate by roughly an equal amount, and this expectation is confirmed by the estimates of Sellon and Seibert [1982]. Hence, I attribute a one percentage point incrcase in the funds rate to the discount rate increase. Sellon and Seibert estimate that a one percent surcharge raised the funds rate by approximately 65 basis points, and I use that estimate in this paper. ${ }^{13}$

12 Sellon [1985] shows that the estimated relationship between the spread and the level of borrowing in the post-October 1979 period is sensitive to the choice of the dependent variable in the estimated regression equation and the treatment of the surcharge in the equation. In equations with a surcharge variable, the estimated effect on the spread of a $\$ 100$ million increase in the level of borrowing is 31 basis points when borrowing is the dependent variable and 17 basis points when the spread is the dependent variable, although the latter estimate drops sharply if a correction for autocorrelation is made. In equations with borrowing as the dependent variable and a surcharge dummy variable entered multiplicatively with the spread, the effect of a $\$ 100$ million increase in borrowing when the surcharge is zero is 20 basis points in one subperiod and 31 basis points in the second subperiod.

13 As Sellon [1985, pp. 12-18] emphasizes, it is difficult to obtain meaningful estimates of the impact of the surcharge on the funds rate. The surcharge was imposed only two times, and the first occurred in the midst of the 1980 credit controls. The effect of the elimination of the surcharge on the funds rate is particularly difficulc to evaluate because in both cases the elimination occurred just as the funds rate was slipping below the discount rate and the Desk was effectively going off the nonborrowed reserve procedures. In any case, attributing the funds rate declines in these periods to a breakdown in the procedures rather than to the elimination of the surcharge would not affect the overall allocation of funds rate movements between those due to the automatic adjustment and those due to judgmental Fed decisions, since movements in the funds rate resulting from either cause fall into the latter category.
To sum up, estimates of the contribution of the various factors to movements in the funds rate over the intermeeting period ending May 20, 1981 are:

FOMC lowering of borrowed reserve target at beginning of period:

Automatic upward adjustment of borrowed reserve target:

Judgmental upward adjustments in borrowed reserve target:

Discount rate increase:

Surcharge:

The estimate of the total rise in the funds rate over this intermeeting period is 3.40 percentage points, which is somewhat below the actual increase of 3.96 percentage points. A little under 30 percent of the estimated increase in the funds rate can be attributed to the automatic adjustment. The rest resulted from judgmental decisions of the Fed.

Breakdown in the automatic adjustment The automatic adjustment illustrated in Table I did not function whenever the demand for total reserves fell below the nonborrowed reserve path. ${ }^{14}$ In this situation the federal funds rate dropped below the discount rate and fell to whatever level the FOMC set as a constraint (Levin and Meek [1981, p. 26]). In such periods borrowing at the discount window was no longer sensitive to the spread between the funds rate and the discount rate. Consequently, cuts in the discount rate had no effect on the funds rate. There were three such episodes in the October 1979 to October 1982 period: (1) from the middle of the intermeeting period ending May 21, 1980 to the first week of the intermeeting period ending September 17, 1980; (2) most of the intermeeting period ending August 25, 1982; and (3) a brief period at the beginning of the intermeeting period ending December 23, 1981.

Table II shows the intermeeting period ending July 9,1980 , when the funds rate was -well below the discount rate. In this situation the Desk simply fixed the average borrowed reserve target at a minimal level of $\$ 100$ million and adjusted nonborrowed

14 Strictly speaking, the procedure also broke down when the FOMC had flexible short-run targets for the monetary aggregates within the intermeeting period. For instance, in the intermeeting period ending July 8, 1981 the FOMC's short-run target for M1B was 3 percent or less. In this period the Desk accommodated the weak growth in M1B by making weekly downward adjustments in the reserve paths. (See Appendix A, Table 16, in Cook [1989].) 
Table II

BEHAVIOR OF BORROWED RESERVES, THE DISCOUNT RATE, AND THE FUNDS RATE

IN THE INTERMEETING PERIOD ENDING JULY 9, 1980

\begin{tabular}{|c|c|c|c|c|c|c|c|c|c|c|c|}
\hline \multirow[b]{3}{*}{ Week } & \multicolumn{2}{|c|}{$\begin{array}{c}\text { Monetary Aggregates } \\
\text { (annualized growth rates) }\end{array}$} & \multicolumn{6}{|c|}{$\begin{array}{c}\begin{array}{c}\text { Adjustment Borrowing (excludes extended credit) } \\
(\$ \text { millions })\end{array} \\
\end{array}$} & \multicolumn{2}{|l|}{$\begin{array}{l}\text { Federal Funds Rate } \\
\text { (percent) }\end{array}$} & \multirow{2}{*}{$\frac{\begin{array}{c}\text { Discount } \\
\text { Rate } \\
\text { (percent) }\end{array}}{\text { (11) }}$} \\
\hline & (1) & (2) & (3) & (4) & (5) & (6) & (7) & (8) & (9) & (10) & \\
\hline & $\begin{array}{c}\text { M1A/M1B/M2 } \\
\text { Target from } \\
\text { March to } \\
\text { June }\end{array}$ & $\begin{array}{c}\text { M1A/M1B/M2 } \\
\text { Proiection } \\
\text { on Friday } \\
\end{array}$ & $\begin{array}{c}\text { Initial } \\
\text { Average } \\
\text { Target }\end{array}$ & $\begin{array}{l}\text { Gap Between } \\
\text { Projected } \\
\text { and Path } \\
\text { Level of } \\
\text { Total } \\
\text { Reserves } \\
\end{array}$ & $\begin{array}{c}\text { Judgmental } \\
\text { Adiustments } \\
\text { to Average } \\
\text { Target } \\
\end{array}$ & $\begin{array}{l}\text { Revised } \\
\text { Average } \\
\text { Target }\end{array}$ & $\begin{array}{c}\text { Target for } \\
\text { Remaining } \\
\text { Weeks in } \\
\text { Period }\end{array}$ & $\begin{array}{c}\text { Actual } \\
\text { Borrowing for } \\
\text { Current Week }\end{array}$ & Expected & Actual & \\
\hline May 28 & $\begin{array}{l}\text { The [reserve] paths were } \\
\text { constructed in accordance } \\
\text { with the Committee's } \\
\text { decision to accept some } \\
\text { increase in monetary } \\
\text { growth during May and } \\
\text { June relative to the esti- } \\
\text { mates presented at the } \\
\text { [FOMC] meeting... }\end{array}$ & $\begin{array}{c}7.1 / 5.3 / 6.7 \\
\text { (May) } \\
10.0 / 12.0 / 9.1 \\
\text { (June) }\end{array}$ & 100 & 0 & 0 & 100 & 100 & 307 & $\begin{array}{l}\text { Achieving the frictional level of } \\
\text { borrowing implied that Federal funds } \\
\text { probably would not trade above the } \\
\text { discount rate, and might well decline } \\
\text { from the approximate } 103 / 4 \text { percent } \\
\text { average of the previous week. The } \\
\text { Committee had set a lower bound on } \\
\text { its Federal funds rate range of } 81 / 2 \\
\text { percent (with a top of } 14 \text { percent) but } \\
\text { indicated a preference that funds not } \\
\text { trade persistently at rates below about } \\
91 / 2 \text { percent without the opportunity } \\
\text { for further Committee consultation. }\end{array}$ & 9.46 & 13 \\
\hline June 4 & & $\begin{array}{c}4.5 / 2.5 / 8.8 \\
\text { (May) } \\
10.0 / 12.4 / 12.5 \\
\text { (June) }\end{array}$ & 100 & $0^{\mathrm{a}}$ & 0 & 100 & 31 & 105 & $\begin{array}{l}\text {.. . achieving such low adjustment } \\
\text { borrowing levels implied that the } \\
\text { Federal funds rate might well test the } \\
91 / 2 \text { percent level late in the } \\
\text { statement week. }\end{array}$ & 10.74 & 12 \\
\hline June 11 & & $\begin{array}{c}2.9 / 0.9 / 8.5 \\
\text { (May) } \\
8.7 / 11.1 / 11.1 \\
\quad \text { (June) }\end{array}$ & 100 & -6 & 0 & *94 & 0 & 32 & $\begin{array}{l}\text { Since it appeared likely that Federal } \\
\text { funds would trade below } 91 / 2 \text { percent } \\
\text { if the Desk sought these levels of } \\
\text { adjustment borrowing and excess } \\
\text { reserves, the Account Management } \\
\text { consulted with the Committee. }\end{array}$ & 9.68 & 12 \\
\hline June 18 & & $\begin{array}{c}3.2 / 1.5 / 9.2 \\
\text { (May) } \\
9.4 / 11.4 / 13.5 \\
\text { (June) }\end{array}$ & 100 & $o^{c}$ & 0 & $* 100$ & 0 & 120 & n.a. & 8.99 & 11.14 \\
\hline \multicolumn{12}{|c|}{ Second Subperiod } \\
\hline June 25 & & $\begin{array}{l}1.6 /-0.3 / 8.6 \\
\text { (May) } \\
13.0 / 15.5 / 16.1 \\
\text { (June) }\end{array}$ & 100 & $0^{d}$ & 0 & 100 & 100 & 44 & n.a. & 9.08 & 11 \\
\hline July 2 & $\cdot$ & $\begin{array}{c}0.7 /-1.2 / 9.1 \\
\text { (May) } \\
14.4 / 17.4 / 17.2 \\
\text { (June) }\end{array}$ & 100 & 0 & 0 & $* 100$ & 128 & 74 & n.a. & 9.41 & 11 \\
\hline July 9 & & $\begin{array}{c}13.7 / 16.8 / 17.3 \\
\text { (June) }\end{array}$ & 100 & 0 & ${ }^{*}-27^{e}$ & *73 & 100 & 17 & n.a. & 9.26 & 11 \\
\hline
\end{tabular}

as in the previous week the average nonborrowed reserve path ... was set equal to the total reserve path less $\$ 100$ million on average for adjustment borrowing.

b The Committee, in a telephone conference on Thursday, June 5, agreed to allow full use of the entire Federal funds rate range down to $81 / 2$ percent, provided that the dollar did not come under undue pressure in the foreign exchange market.

c The average total resenves path for the four-week period ending June 18 was ralsed slightly to align it with the four-week average of actual and projected total reserves. This was done in accordance with the decision to set the path equal to the

projection so long as the projection exceeded the original path deemed consistent with the minimally acceptable growth rates of the aggregates for May-June.

The path was not lowered by the full amount of the accepted [technical] revisions because that would have resulted in a path level that implied adjustment borrowings in excess of the $\$ 100$ million level initialtiy sought by the Comminttee.

In view of the imminence of the Committee meeting it was decided not to push borrowing to higher levels to make up for shortfalls in the previous two weeks.

* Number not explicitly given in the Report of Open Market Operations (See Appendix for explanation). 
reserves to reflect changes in required reserves. ${ }^{15}$ The funds rate was effectively set on a week-to-week basis at a level acceptable to the FOMC. Also, the two cuts in the discount rate in this period had no apparent effect on the actual funds rate or on the funds rate expected by the Desk.

\section{Allocation of Movements in the Funds Rate over the Post-October 1979 Period}

Table III provides estimates of the movements in the funds rate over the period from October 1979 through June 1982, excluding the intermeeting periods ending July 9, 1980, August 13, 1980, and August 25, 1982, when the funds rate was below the discount rate and the automatic adjustment was not functioning. ${ }^{16}$ As in the example above, Table III allocates movements in the funds rate over this period to five sources: the automatic adjustment in the borrowed reserve target in the intermeeting period, judgmental adjustments in the borrowed reserves target in the intermeeting period, adjustments in the borrowed reserve target made at FOMC meetings, discount rate changes, and changes in the discount rate surcharge. The assumptions used to allocate movements in the funds rate to each of these factors are: (1) an increase or decrease in the weekly borrowed reserve target of $\$ 100$ million causes a rise or fall in the funds rate of 25 basis points, (2) a rise in the discount rate causes an equal rise in the funds rate, (3) a one percent surcharge raises the funds rate by 65 basis points, and (4) a decrease in the discount rate has no effect on the funds rate.

The first three assumptions were discussed above. The fourth reflects the circumstance that most discount rate cuts in this period occurred when the funds rate was below the discount rate, and in this situation cuts in the discount rate would not be expected to affect the funds rate. This expectation is confirmed by Sellon and Seibert [1982], who find that reductions in the discount rate in this period had a negli-

15 The breakdown of the procedures in this period is discussed in the New York Fed's 1980 review of monetary policy and open market operations [1981, p. 72]: "As implied borrowing moved down to frictional levels, the Desk began to encounter operational difficulties that recurred from time to time through July."

16 I exclude the intermeeting perind ending October 6, 1982 from the discussion altogether because the nonborrowed reserve procedures had effectively been abandoned by this time even though Chairman Volcker's announcement of the de-emphasis of M1 did not come until the end of the period. In line with the FOMC's instructions, the Desk in this period adjusted the reserve paths to prevent the funds rate from rising in reaction to the rapid money growth in August and September, and the expected funds rate remained around 10 percent throughout the period. (See Appendix A, Table 26, in Cook [1989].) gible effect on the funds rate. The Fed seemed to be aware of the funds rate's insensitivity to discount rate cuts at the time, as it generally accompanied reductions in the discount rate with announcements indicating the reductions were solely to realign the discount rate with market rates. In contrast, the Fed always accompanied increases in the discount rate with more aggressive announcements indicating the increases were being made partially, if not totally, for policy reasons. ${ }^{17}$

The totals at the bottom of Table III show that based on the assumptions above, the automatic adjustment in the borrowed reserve target contributed 22.02 percentage points to movements (in absolute value) in the funds rate over the post-October 1979 period. The contribution of the discount rate plus the surcharge was 14.81 percentage points. Judgmental adjustments in the borrowed reserve target caused movements of 9.83 percentage points. ${ }^{18}$ In all but three cases the judgmental adjustments were in the same direction as the automatic adjustment. ${ }^{19}$ Target changes at FOMC meetings contributed funds rate movements of 8.06 percentage points, the major part of which was in the first six intermeeting periods. ${ }^{20}$ After that the FOMC generally set the initial borrowing target close to the last weekly borrowing target in the previous period.

The estimates in Table III can also be used to evaluate the relative importance of different factors

17 Cook and Hahn [1986] provide a record of the discount rate
announcements in this period. Seven of the ten cuts in the dis-
count rate were accompanied by announcements indicating the
cuts were being taken solely to realign the rate with market rates,
whereas none of the six increases in the discount rate were ac-
companied by this type of announcement.
18 In the intermeeting period ending February 6,1980 , the
weekly borrowed reserve target fell even though the average
borrowed reserve target rose. As shown in the Appendix, this
oddity resulted from large misses in the weekly target. In this
case, I set the contribution of changes in the average borrowed
reserve target to movements in the funds rate at zero.

19 As shown in the Appendix, in the intermeeting period ending February 4, 1981, there was a small decrease in the average borrowed rescrve target and a much larger decrease in the weekly target, while the automatic adjustment in the average borrowed reserve target was negative and the judgmental adjustment in the average borrowed reserve target was positive. In this situation, the estimated impact on the funds rate of both the automatic and judgmental adjustments to the borrowing target were magnificd given the nature of the estimation procedure as described in the text. These estimates are offsetting, however, and they have virtually no effect on the overall estimate of movements in the funds rate due to automatic versus judgmental adjustments in the average borrowed reserve target.

20 The sum of the estimated contributions to movements in the funds rate for all the factors is bigger than the total estimated movement because factors sometimes pulled the funds rate in opposite directions within a period. 
Table III

ESTIMATES OF MOVEMENTS IN THE FUNDS RATE

\begin{tabular}{|c|c|c|c|c|c|c|c|}
\hline \multirow[b]{2}{*}{$\begin{array}{l}\text { Intermeeting } \\
\text { Period } \\
\text { Ending }\end{array}$} & \multicolumn{5}{|c|}{ Contributing Factors } & \multirow[b]{2}{*}{$\begin{array}{c}\text { Total } \\
\text { Estimated } \\
\text { Change } \\
\end{array}$} & \multirow[b]{2}{*}{$\begin{array}{l}\text { Actual } \\
\text { Change }\end{array}$} \\
\hline & $\begin{array}{l}\text { Target } \\
\text { Change } \\
\text { by FOMC }\end{array}$ & $\begin{array}{l}\text { Automatic } \\
\text { Adjustment }\end{array}$ & $\begin{array}{l}\text { Judgmental } \\
\text { Adjustments }\end{array}$ & $\begin{array}{l}\text { Discount } \\
\text { Rate } \\
\text { Increase }\end{array}$ & Surcharge & & \\
\hline & (1) & (2) & (3) & (4) & (5) & (6) & (7) \\
\hline $\begin{array}{l}\text { 21-Nov-79 } \\
\text { 09-Jan-80 } \\
\text { 06-Feb-80 } \\
\text { 19-Mar-80 } \\
\text { 23-Apr-80 } \\
21 \text {-May-80 } \\
\text { 09-Jul-80 } \\
13-\text { Aug-80 } \\
\text { 17-Sep-80 } \\
\text { 22-Oct-80 } \\
\text { 19-Nov-80 } \\
\text { 17-Dec-80 } \\
\text { 04-Feb-81 } \\
\text { 01-Apr-81 } \\
\text { 20-May-81 } \\
\text { 08-Jul-81 } \\
\text { 19-Aug-81 } \\
\text { 07-Oct-81 } \\
\text { 18-Nov-81 } \\
\text { 23-Dec-81 } \\
\text { 03-Feb-82 } \\
\text { 31-Mar-82 } \\
\text { 19-May-82 } \\
\text { 30-Jun-82 } \\
\text { 25-Aug-82 }\end{array}$ & $\begin{array}{r}0.00 \\
-0.05 \\
-0.75 \\
1.38 \\
1.41 \\
-0.81 \\
0.25 \\
-0.06 \\
-0.05 \\
-0.01 \\
-0.07 \\
-0.29 \\
-0.32 \\
0.50 \\
-0.03 \\
0.59 \\
0.32 \\
-0.02 \\
-0.08 \\
0.00 \\
-0.13 \\
0.00 \\
-0.64 \\
-0.61 \\
-0.54\end{array}$ & $\begin{array}{r}0.49 \\
-0.52 \\
0.00 \\
1.16 \\
-2.30 \\
-4.18 \\
0.00 \\
0.05 \\
1.22 \\
0.99 \\
0.52 \\
0.18 \\
-3.09 \\
-0.35 \\
0.79 \\
-1.01 \\
-0.15 \\
-1.29 \\
-1.01 \\
0.13 \\
2.01 \\
-0.16 \\
-0.14 \\
0.33 \\
-0.73\end{array}$ & $\begin{array}{r}0.06 \\
-0.48 \\
0.00 \\
1.18 \\
-0.32 \\
0.74 \\
0.00 \\
0.00 \\
0.48 \\
0.45 \\
0.26 \\
0.14 \\
2.09 \\
0.00 \\
0.99 \\
-0.81 \\
-0.07 \\
0.00 \\
-0.12 \\
-0.25 \\
0.99 \\
-0.08 \\
-0.12 \\
0.20 \\
-0.51\end{array}$ & $\begin{array}{l}0.71 \\
0.00 \\
0.00 \\
1.00 \\
0.00 \\
0.00 \\
0.00 \\
0.00 \\
0.00 \\
1.00 \\
0.43 \\
1.57 \\
0.00 \\
0.00 \\
1.00 \\
0.00 \\
0.00 \\
0.00 \\
0.00 \\
0.00 \\
0.00 \\
0.00 \\
0.00 \\
0.00 \\
0.00\end{array}$ & $\begin{array}{r}0.00 \\
0.00 \\
0.00 \\
0.84 \\
1.11 \\
-1.95 \\
0.00 \\
0.00 \\
0.00 \\
0.00 \\
0.56 \\
1.39 \\
0.00 \\
0.00 \\
0.65 \\
0.00 \\
0.00 \\
-0.65 \\
-1.02 \\
-0.93 \\
0.00 \\
0.00 \\
0.00 \\
0.00 \\
0.00\end{array}$ & $\begin{array}{r}1.26 \\
-1.05 \\
-0.75 \\
5.56 \\
-0.11 \\
-6.20 \\
\text { na } \\
\text { na } \\
1.65 \\
2.43 \\
1.71 \\
3.00 \\
-1.32 \\
0.15 \\
3.40 \\
-1.23 \\
0.09 \\
-1.97 \\
-2.23 \\
-1.05 \\
2.88 \\
-0.24 \\
-0.90 \\
-0.07 \\
\text { na }\end{array}$ & $\begin{array}{r}1.10 \\
0.84 \\
-1.14 \\
3.44 \\
1.32 \\
-6.85 \\
-1.45 \\
-0.41 \\
1.79 \\
1.91 \\
2.67 \\
4.61 \\
-2.64 \\
-2.26 \\
3.96 \\
1.04 \\
-1.74 \\
-2.73 \\
-2.29 \\
-0.74 \\
2.34 \\
0.22 \\
-0.32 \\
0.14 \\
-5.77\end{array}$ \\
\hline Absolute Total* & 8.06 & 22.02 & 9.83 & 5.71 & 9.10 & & \\
\hline
\end{tabular}

* Excludes 09-July-80, 13-Aug-80 and 25-Aug-82

over periods of unusually sharp movements in the funds rate. Consider the rise in the funds rate of 10.98 percentage points over the four periods ending December 17,1980 . In this period the estimated increase in the funds rate was 8.79 percentage points, only 2.91 percentage points of which was due to the automatic adjustment. Rises in the discount rate and surcharge were responsible for 4.95 percentage points of the increase, and judgmental adjustments in the borrowed reserve target were responsible for another 1.33 percentage points. ${ }^{21}$

The accompanying chart compares the funds rate predicted by the estimates in Table III to the actual funds rate. Although there are occasionally large errors within individual periods, these tend to be offsetting, so the predicted funds rate does a fairly good job of tracking the actual funds rate. The large

21 This estimate is similar to that made in the New York Federal Reserve Bank's 1980 review of monetary policy and open market operations [1981, p. 64]: "In combination [the discount rate and surchargel appeared to account for about half of the $10 \frac{1}{2}$ percentage point increase in the funds rate over the AugustDecember period. The remaining increase reflected the automatic response of rates to monetary overshoots under the reserve approach and the downward [judgmentall adjustments made to the nonborrowed reserve path." prediction errors in some of the periods reflect the instability of the relationship between the demand for borrowed reserves and the spread between the funds rate and the discount rate. Factors influencing this relationship are the expected direction of monetary policy and the effect of discount window administration on bank borrowing patterns. 22

The discussion above excludes the intermeeting periods ending July 9, 1980, August 13, 1980, and August 25, 1982, when the funds rate was below the discount rate and the automatic adjustment was not in operation. ${ }^{23}$ (It includes, however, the intermeeting period ending December 23,1981 , when the funds rate was below the discount rate for a brief period, and the intermeeting period ending May 21 , 1980 , when the funds rate was below the discount rate the second half of the period.) The funds rate declined 1.86 percentage points over the two intermeeting periods in the summer of 1980 and 5.77 percentage points in the period ending in August 1982.

The central conclusion from Table III is that movements in the funds rate in the post-October 1979 period were not determined primarily by the automatic adjustment of the borrowing target under

22 Levin and Meek [1981, pp. 29-34] discuss some specific periods of difficulty in predicting short-run movements in the funds rate when policy expectations and discount window administration were altering the relationship between borrowing and the spread between the funds rate and the discount rate. Goodfriend [1983] provides a theoretical discussion of the effect of policy expectations and discount window administration on discount window borrowing behavior, and Mengle [1986] describes the ground rules faced by financial institutions when borrowing at the discount window.

23 In the period ending August 25, 1982, borrowing was well above the negligible level usually associated with a negative spread between the funds rate and the discount rate. Apparently, this resulted from the inclusion of some emergency borrowing in the adjustment borrowing category in the aftermath of the Penn Square Bank failure. For instance, in explaining the low funds rate the week of July 28,1982 , when reported adjustment borrowing was $\$ 524$ million, the Report of Open Market Operations indicated that "the amount of adjustment borrowing contained in the total borrowing imposed on the system was fairly low, resulting in less pressure on the money market." 


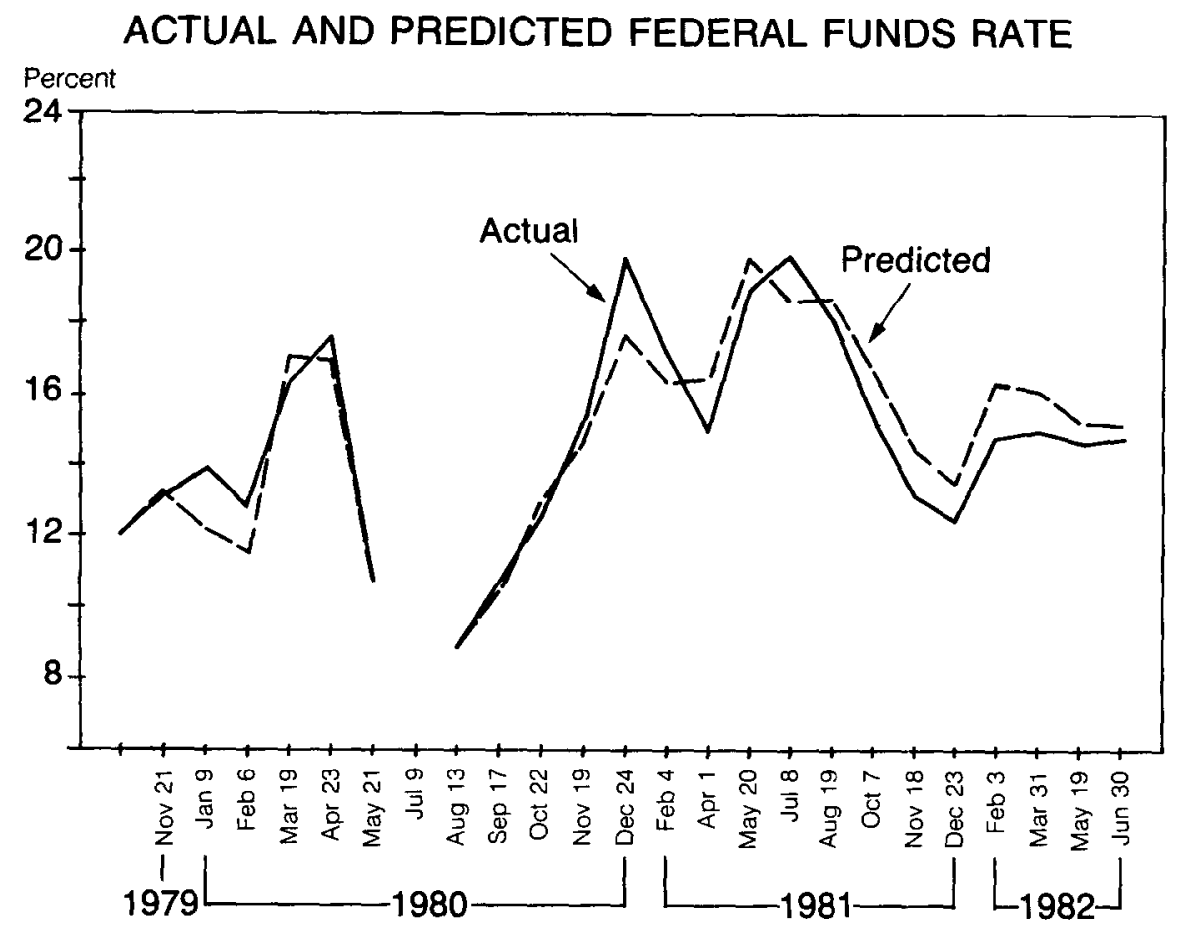

Possible Methodological Problems

This section discusses four questions that might arise regarding the procedure used in allocating movements in the funds rate to the various factors listed above. The main concern is whether the procedure might be biased in favor of the conclusion that movements in the funds rate over this period were largely due to judgmental decisions by the Federal Reserve.

One judgmental decision potentially affecting the funds rate not taken into account in the analysis of the preceding section is how much of the "technical" adjustments the Desk incor-

the nonborrowed reserve operating procedures. In this period the automatic adjustment was responsible for only about one-third of the movement in the funds rate. The other two-thirds resulted from changes in the discount rate and the surcharge, judgmental adjustments in the borrowed reserve target in the intermeeting period or at FOMC meetings, and movements in the funds rate when it was below the discount rate and the automatic adjustment was not in operation. It follows from this conclusion that the greater volatility in interest rates and monetary growth rates observed in this period can not be attributed primarily to the automatic adjustment. ${ }^{24}$

${ }^{24}$ It is of course possible that in this period the Fed's actions affecting the funds rate gave greater weight than earlier to deviations of the money stock from target or to deviations from target of other goals such as inflation. McNees [1986] estimates a Federal Reserve reaction function over the period from the third quarter of 1970 through the second quarter of 1986 with the federal funds rate as the dependent variable (i.e., the Fed's policy instrument). He finds increased emphasis on monetary growth over the period from October 1979 to October 1982, but otherwise concludes that the policy behavior that prevailed in the 1970 s persisted in the 1980 s. Similarly, Karamouzis and Lombra [1988] estimate a Fed reaction function over the 1973-82 period with the funds rate as the dependent variable. They find that the coefficient on the difference between actual and targeted money growth jumped sharply shortly after October 1979 and then fell sharply toward the end of 1982 . porated into the paths for nonborrowed and total reserves. As noted earlier, in setting the total reserve path at the beginning of an intermeeting period the Desk had to allow for the absorption of reserves by excess reserves and by required reserves against deposits such as large CDs not included in M1 and M2. Estimates of these technical factors would change as the intermeeting period progressed. In practice, the Desk used some judgement in deciding how to adjust the total (and nonborrowed) reserve path to reflect changes in the technical factors. This decision influenced the gap between the projected and path levels of total reserves, and consequently affected the borrowed reserve target and the expected federal funds rate in the current week. The Desk on occasion considered the effects on the weekly borrowing target and funds rate in deciding how much of the technical adjustments to include in the paths. ${ }^{25}$

A second question regarding the procedure used to allocate funds rate movements concerns the treatment of the judgmental adjustments to the average borrowed reserve target. Conceptually, one can divide these adjustments into two types: The first to engineer movements in the funds rate that would

25 For example, see Appendix A, Table 10, note 4, and Table 22, note 7, in Cook [1989]. See Levin and Meek [1981, Appendix 1] for a discussion of the technical adjustments in setting the reserve paths. 
not have resulted from the automatic adjustment and the second to prevent funds rate movements resulting from "shifts" in the demand function for borrowed reserves. To illustrate the latter type, suppose that in the first wcek of a four-week period a temporary (i.e., one-week) shift in the demand for borrowed reserves increased desired discount-window borrowing above the amount that normally would have resulted from the prevailing spread between the funds rate and the discount rate. Suppose also that rather than let this shift affect the funds rate, the Desk allowed borrowed reserves to be, say, $\$ 400$ million more than had been targeted (and nonborrowed rescrves $\$ 400$ million less). The following week the Desk could raise the average borrowing target for the four-week period by $\$ 100$ million (400/4), thereby leaving the weekly target for the last three weeks in the period unaffected by the temporary shift in the borrowed reserve function the first week. ${ }^{26}$

One might argue that adjustments in the average borrowed reserve target to accommodate past misses in the weekly borrowed reserve target resulting from shifts in the borrowed reserve function should not be counted as judgmental-as they were in the preceding section-because such adjustments were intended to prevent movements in the funds rate not resulting from the automatic adjustment. In many cases, however, it is difficult to identify from the Report of Open Market Operations those adjustments in the average borrowed reserve target made to offset past misses in the weekly borrowing target clearly resulting from shifts in the borrowed reserve function. At most, 30 percent of the judgmental adjustments at the end of the intermeeting periods were of this nature. ${ }^{27}$ If these adjustments were removed from the judgmental category, then additions to this category should be made for those occasions when there was a shift in the borrowed reserve function that the Desk did not accommodate, but such occasions can not be identified from the Report of Open Market Operations. On balance, it is possible that the inclusion in the judgmental category of those adjustments made to accommodate shifts in the borrowed reserve function may have biased upward the estimate in the previous section of funds rate movements due to judgmental actions, but the bias in any case was small.

26 For examples of this type of adjustment in the average borrowed reserve target see Appendix A, Table 6, note 2, and Table 16, note 10, in Cook [1989].

7. Note that it is only the end-of-pcriod adjustments that are relevant to this discussion and the previous discussion on technical adjustments, since the estimates in Table III are based on end-of-period figures.
The third question regarding the procedure used here is its focus on the extent to which movements in the funds rate were auromatically caused by deviations of M1 from its short-run targets. Because the short-run targets were taken as given, a potential source of judgmental influence on the funds rate not captured by the analysis was the relationship between the short-run targets for $\mathrm{M} 1$ and the annual targets. 1 did not examine that relationship in this paper, but it clearly was not uniform over the three-year period. An important example is the second quarter of 1981 when the FOMC formally accepted short-run growth rates of M1 that were below the rate consistent with its annual target (adjusted for the estimated impact of NOW account shifts). The funds rate rose from 14.93 percent at the end of the April 1, 1981 intermeeting period to 19.93 percent at the end of the July 8, 1981 intermeeting period even though M1 was at the lower bound or below its annual target range throughout this interval..$^{28}$ As a result, M1 finished 1981 well below its annual target range. (M2, however, finished the year around the top of its range.)

A final issue, and probably the most important, is that the analysis implicitly assumes that movements in the funds rate resulting from judgmental actions were not systematically related to movements resulting from the automatic adjustment. If they were, then one might justifiably argue that movements in the funds rate over this period were, in fact, automatically determined. To consider this possibility, I regressed the period by period changes in the funds rate resulting from all judgmental actions (JUDG) - the sum of columns 1, 3, 4, and 5 in Table III-on the changes resulting from the automatic adjustment (AUTO)-column 2 in Table III. The regression results were (t-statistics in parentheses):

$$
J U D G=\underset{(1.74)}{0.54}+\underset{(2.30)}{0.55}\left(\text { AUTO) } \quad R^{2}=.22\right.
$$

The cocfficient of AUTO is positive and significant at the 5 percent level, indicating there was some tendency for judgmental actions to reinforce the effect of the automatic adjustment on movements in the funds rate. The low $\mathrm{R}^{2}$, however, indicates that the proportion of the judgmental movement in the funds rate that was systematically linked to the automatic adjustment was small. Moreover, this

28 See Appendix A, Table 16, in Cook [1989] and the discussion of this period in Hetzel [1986, pp. 26-28] and Broaddus and Goodfriend [1984, pp. 7-8]. 
regression excludes data from the intermeeting periods when the automatic adjustment in the borrowed reserve target was not functioning and movements in the funds rate were determined solely on a judgmental basis (July 9, 1980, August 13, 1980, and August 25, 1982). ${ }^{29}$ On balance, the evidence indicates only a weak link between movements in the funds rate resulting from judgmental actions and movements resulting from the automatic adjustment.

To summarize, it can be argued that some of the adjustments in the average borrowed reserve target that I have counted as judgmental were consistent with the automatic adjustment because they were intended to accommodate past misses in the weekly borrowing target associated with shifts in the bor-

29 The regression also excludes the period ending February 4 , 1981 , when there are large estimates-opposite in sign - of the contribution to funds rate movements of the automatic and judgmental adjustments in the average borrowed reserve target. (See footnote 19). The regression results deteriorate sharply when this period is included. rowed reserve function. (Although that argument is not compelling in my view, because there was no clear rule governing when such adjustments would be made.) Also, the evidence indicates that a small part of the movement in the funds rate due to judgmental actions was systematically related to the movement resulting from the automatic adjustment. These factors may exert some downward bias on the estimate of the proportion of the movement in the funds rate in the post-October 1979 period resulting from the automatic adjustment. Working in the opposite direction, however, is the judgmental effect on the funds rate resulting from the lack of rules (1) specifying how much of the technical adjustments to incorporate into the reserve paths and (2) linking the short-run M1 targets to the annual target. On balance, the questions raised in this section do not appear to significantly weaken the earlier conclusion that movements in the funds rate from October 1979 to October 1982 were largely determined on a judgmental basis.

\section{References}

Axilrod, Stephen H. "U.S. Monetary Policy in Recent Years: An Overview." Federal Reserve Bulletin 71 (January 1985): 14-24.

Broaddus, Alfred, and Timothy Cook. "The Relationship between the Discount Rate and the Federal Funds Rate under the Federal Reserve's Yost-October 6, 1979 Operating Procedure." Federal Reserve Bank of Richmond Economic Review 69 (January/February 1983): 12-15.

Broaddus, Alfred, and Marvin Goodfriend. "Base Drift and the Longer Run Growth of M1: Experience from a Decade of Monetary Targeting." Federal Reserve Bank of Richmond Economic Reviese 70 (November/December 1984): 3-14.

Cook, Timothy. "Determinants of the Federal Funds Rate: 1979-1982." Working Paper 88-5, Federal Reserve Bank of Richmond, March 1989.

Cook, Timothy, and Thomas Hahn. "The Information Content of Discount Rate Announcements and Their Effect on Market Interest Rates." Working Paper 86-5. Federal Reserve Bank of Richmond, September 1986.

Federal Reserve Bank of New York. "Monetary Policy and Open Market Operations in 1979." Federal Reserve Bank of New York Quarterly Reviese 5 (Summer 1980): 50-64.

"Monetary Policy and Open Market Operations in 1980." Federal Reserve Bank of New York Quarterly Reviero 6 (Summer 1981): 56-75.

"Monetary Policy and Open Market Operations in 1981." Federal Reserve Bank of New York Quarterly Reviere 7 (Spring 1982): 34-52.
_ "Monetary Policy and Open Market Operations in 1982." Federal Reserve Bank of New York Quarterly Review 8 (Spring 1983): 37-54.

Goodfriend, Marvin. "Discount Window Borrowing, Monetary Policy, and the Post-October 6, 1979 Federal Reserve Operating Procedure." Joumal of Monetary Economics 12 (September 1983): 343-56.

Goodfriend, Marvin, Gary Anderson, Anil Kashyap, George Moore, and Richard Porter. "A Weekly Rational Expectations Model of the Nonborrowed Reserve Operating Procedure." Federal Reserve Bank of Richmond Economic Review 72 (January/February 1986): 11-28.

Hetzel, Robert L. "Monetary Policy in the Early 1980s." Federal Reserve Bank of Richmond Economic Revieve 72 (March/April 1986): 20-32.

"The October 1979 Regime of Monetary Control and the Behavior of the Money Supply in 1980." Joumal of Money, Credit, and Banking 14 (May 1982): 234-51.

Karamouzis, Nicholas, and Raymond Lombra. "Federal Reserve Policymaking: An Overview and Analysis of the Policy Process." Paper presented at the Carnegie-Rochester Public Policy Conference, April 22-23, 1988.

Levin, Fred J., and Paul Meek. "Implementing the New Operating Procedures: The View from the Trading Desk." In Nero Monetary Control Procedures, edited by Stephen $\mathrm{H}$. Axilrod. Washington: Board of Governors of the Federal Reserve System, 1981. 
McNees, Stephen K. "Modeling the Fed: A Forward-Looking Monetary Policy Reaction Function." Federal Reserve Bank of Boston Nero England Fronomic Review (November/ December 1986), pp. 3-8.

Mengle, David L. "The Discount Window." In Instruments of the Money Market, 6th ed., edited by Timothy Q. Cook and Timothy D. Rowe. Richmond: Federal Reserve Bank of Richmond, 1986.

Morris, Frank E. "Monetarism without Money." Federal Reserve Bank of Boston New England Economic Reviero (March/April 1983), pp. 5-9.

Poole, William. "Federal Reserve Operating Procedures: A Survey and Evaluation of the Historical Record Since October 1979." Joumal of Money, Credit, and Banking 14 (November 1982, pt. 2): 575-96.
Sellon, Gordon H., Jr. "Estimation of the Borrowings Function: Pre and Post-October 1979." Research Working Papes 85-04. Federal Reserve Bank of Kansas City, July 1985.

Sellon, Gordon H., Jr., and Diane Seibert. "The Discount Rate: Experience under Reserve Targeting." Federal Reserve Bank of Kansas City Fconomic Review 67 (September/October 1982): 3-18.

Spindt, Paul A., and Vefa Tarhan. "The Federal Reserve's New Operating Procedures: A Post Mortem." Joumal of Monetary Economics 19 (January 1987): 107-23.

Stigum, Marcia. The Money Market. Homewood, Illinois: Dow Jones-Irwin, 1983.

Volcker, Paul A. "The New Federal Reserve Technical Procedures for Controlling Money." Appendix to a statement by Paul A. Volcker, Chairman of the Board of Governors of the Federal Reserve System, before the Joint Economic Committee, February 1, 1980.

\section{APPENDIX}

This Appendix table arranges in compact form the data from the tables in my working paper [1989] for each of the twenty-six periods between FOMC meetings from October 1979 to October 1982. All information in the table comes from the Report of Open Market Operations.

The first through sixth columns in the table show targeted and actual borrowing levels at the discount window. All figures in these columns are in millions. The first column shows the initial target set by the FOMC for average borrowed reserves in the intermeeting period. The second column shows the gap between the projected and path levels of average total reserves. The third column shows any judgmental adjustments in the average borrowed reserve target. The fourth column adds to the initial target for average borrowed reserves the total reserve gap plus any judgmental adjustments to obtain a revised target for average borrowed reserves. The fifth column shows the borrowed reserve target for the current and remaining weeks in the intermeeting period (or subperiod). This column is derived from the revised average target for borrowed reserves and thc actual level of borrowing in the weeks of the period that have already elapsed. Column six shows the actual borrowing level for the week.

In the first few intermeeting periods the Report of Open Market Operations gives some of the reserve numbers in approximate terms (for example, rounded to the nearest $\$ 100$ million). In these periods there are some small inconsistences between the revised average borrowed reserve target and the borrowed reserve target for the current and remaining weeks.
In some cases-especially in the first few intermeeting periods - numbers for some of the items are not explicitly mentioned in the Report of Open Market Operations. The borrowed reserve target for the current and remaining weeks in the intermeeting period and the gap between the projected and path levels of total reserves are always given, however, and these can be used to derive the other numbers. Knowledge of the borrowing target for the current and remaining weeks in the intermeeting period together with past levels of borrowing can be used to derive the revised target for average borrowed reserves. This target in combination with the total reserve gap and the initial borrowed reserve target specified by the FOMC can be used to derive a figure for judgmental adjustments in the average borrowed reserve target. Numbers not explicitly given in the Report of Open Market Operations, but derived by me, are denoted by an asterik (*).

The seventh column in the table shows the midpoint of the federal funds rate range expected by the Desk near the beginning of the statement week (usually on Friday), and the eighth column shows the actual weekly average funds rate. The seventh column is left blank if there is no clear midpoint to the expected funds rate range in the Report of Open Market Operations, and the column has an "na" if there is no discussion of the expected funds rate in the Report. The last two columns in the table show the discount rate and surcharge.

In the second subperiod of the intermeeting period ending July 8,1981 , the borrowed rescrve target was lowered from $\$ 2100$ million to $\$ 1800$ million in an FOMC telephone conference. Rather than treating 
this as a separate period, I treat it as a judgmental adjustment in the borrowed reserve target in the middle of the July 8, 1981 intermeeting period. In the week of November 28, 1979 there was $\$ 175$ million "as of" borrowing that was reclassified as nonborrowed reserves the week of December 19, 1979. In the week of January 6,1982 the borrowed reserve target was set at $\$ 1.0$ billion for the current week (the year-end week) and $\$ 465$ million for each of the final four weeks in the period. The borrowing target was changed in the middle of the weeks of February 25, 1981 and December 23, 1981 following FOMC meetings.

\begin{tabular}{|c|c|c|c|c|c|c|c|c|c|c|}
\hline \multirow[b]{2}{*}{ Date } & \multicolumn{6}{|c|}{ BORROWED RESERVES } & \multicolumn{2}{|c|}{ FUNDS RATE } & \multicolumn{2}{|c|}{ DISCOUNT RATE } \\
\hline & $\begin{array}{c}\text { Initial } \\
\text { Average } \\
\text { Target } \\
\text { (1) } \\
\end{array}$ & $\begin{array}{c}\text { Total } \\
\text { Reserve } \\
\text { Gap } \\
\text { (2) } \\
\end{array}$ & $\begin{array}{c}\text { Judgmental } \\
\text { Adjustments } \\
\text { (3) }\end{array}$ & $\begin{array}{c}\text { Revised } \\
\text { Average } \\
\text { Target } \\
(4) \\
\end{array}$ & $\begin{array}{c}\text { Target for } \\
\text { Remaining } \\
\text { Weeks } \\
(5) \\
\end{array}$ & $\begin{array}{c}\text { Actual } \\
\text { Borrowing } \\
\text { (6) }\end{array}$ & $\begin{array}{l}\text { Midpoint } \\
\text { Expected } \\
\text { Funds Rate } \\
\text { (7) } \\
\end{array}$ & $\begin{array}{c}\text { Actual } \\
\text { Funds } \\
\text { Rate } \\
(8) \\
\end{array}$ & $\begin{array}{c}\text { Discount } \\
\text { Rate } \\
(9) \\
\end{array}$ & $\begin{array}{c}\text { Surcharge } \\
(10)\end{array}$ \\
\hline $\begin{array}{l}10-0 c t-79 \\
17-0 c t-79 \\
24-0 c t-79 \\
31-0 c t-79\end{array}$ & $\begin{array}{l}1500 \\
1500 \\
1500 \\
1500\end{array}$ & $\begin{array}{r}0 \\
200 \\
\star 467 \\
360\end{array}$ & $\begin{array}{r}0 \\
0 \\
0 \\
* 122\end{array}$ & $\begin{array}{r}1500 \\
* 1700 \\
* 1967 \\
* 1982\end{array}$ & $\begin{array}{l}1500 \\
1800 \\
2700 \\
2500\end{array}$ & $\begin{array}{r}938 \\
1530 \\
2960 \\
3056\end{array}$ & & $\begin{array}{l}12.00 \\
13.22 \\
15.14 \\
15.61\end{array}$ & $\begin{array}{l}11.29 \\
12 \\
12 \\
12\end{array}$ & $\begin{array}{l}0 \\
0 \\
0 \\
0\end{array}$ \\
\hline $\begin{array}{l}\text { 07-Nov-79 } \\
14-\text { Nov-79 } \\
21 \text {-Nov-79 }\end{array}$ & $\begin{array}{l}1500 \\
1500 \\
1500\end{array}$ & $\begin{array}{r}0 \\
240 \\
300\end{array}$ & $\begin{array}{r}0 \\
0 \\
* 35\end{array}$ & $\begin{array}{r}1500 \\
+1740 \\
* 1835\end{array}$ & $\begin{array}{l}1500 \\
1650 \\
1720\end{array}$ & $\begin{array}{l}1928 \\
1857 \\
1865\end{array}$ & $\begin{array}{l}13.50 \\
13.50 \\
13.50\end{array}$ & $\begin{array}{l}13.77 \\
13.30 \\
13.10\end{array}$ & $\begin{array}{l}12 \\
12 \\
12\end{array}$ & $\begin{array}{l}0 \\
0 \\
0\end{array}$ \\
\hline $\begin{array}{l}\text { 28-Nov-79 } \\
\text { 05-Dec-79 } \\
12-\text { Dec-79 } \\
19-\text { Dec-79 }\end{array}$ & $\begin{array}{l}1700 \\
1700 \\
1700 \\
1700\end{array}$ & $\begin{array}{r}0 \\
100 \\
0 \\
0\end{array}$ & $\begin{array}{r}0 \\
0 \\
0 \\
-100\end{array}$ & $\begin{array}{r}1700 \\
* 1800 \\
* 1700 \\
* 1600\end{array}$ & $\begin{array}{l}1700 \\
1800 \\
1500 \\
1500\end{array}$ & $\begin{array}{c}2021 / 1846 \\
1819 \\
1291 \\
1684\end{array}$ & $\begin{array}{l}13.25 \\
13.25 \\
13.25 \\
13.25\end{array}$ & $\begin{array}{l}12.46 \\
13.77 \\
13.79 \\
13.90\end{array}$ & $\begin{array}{l}12 \\
12 \\
12 \\
12\end{array}$ & $\begin{array}{l}0 \\
0 \\
0 \\
0\end{array}$ \\
\hline $\begin{array}{l}26-D e c-79 \\
02-J a n-80 \\
09-\operatorname{Jan}-80\end{array}$ & $\begin{array}{l}1700 \\
1700 \\
1700\end{array}$ & $\begin{array}{l}-400 \\
-280 \\
-200\end{array}$ & $\begin{array}{r}-200 \\
-150 \\
*-182\end{array}$ & $\begin{array}{r}1100 \\
* 1270 \\
* 1318\end{array}$ & $\begin{array}{l}1100 \\
1300 \\
1300\end{array}$ & $\begin{array}{l}1224 \\
1431 \\
732\end{array}$ & $\begin{array}{l}13.00 \\
13.00 \\
\mathrm{na}\end{array}$ & $\begin{array}{l}13.49 \\
14.04 \\
13.94\end{array}$ & $\begin{array}{l}12 \\
12 \\
12\end{array}$ & $\begin{array}{l}0 \\
0 \\
0\end{array}$ \\
\hline $\begin{array}{l}\text { 16-Jan-80 } \\
23-J a n-80 \\
30-J a n-80 \\
06-F e b-80\end{array}$ & $\begin{array}{l}1000 \\
1000 \\
1000 \\
1000\end{array}$ & $\begin{array}{r}0 \\
0 \\
-50 \\
-85\end{array}$ & $\begin{array}{r}0 \\
0 \\
0 \\
\times 320\end{array}$ & $\begin{array}{r}1000 \\
1000 \\
* 950 \\
* 1235\end{array}$ & $\begin{array}{r}1000 \\
940 \\
694 \\
700\end{array}$ & $\begin{array}{r}1223 \\
1197 \\
1821 \\
759\end{array}$ & $\begin{array}{c}13.63 \\
n a\end{array}$ & $\begin{array}{l}13.91 \\
13.77 \\
13.54 \\
12.80\end{array}$ & $\begin{array}{l}12 \\
12 \\
12 \\
12\end{array}$ & $\begin{array}{l}0 \\
0 \\
0 \\
0\end{array}$ \\
\hline $\begin{array}{l}13-\text { Feb-80 } \\
20-F e b-80 \\
27-F e b-80\end{array}$ & $\begin{array}{l}1250 \\
1250 \\
1250\end{array}$ & $\begin{array}{r}-38 \\
313 \\
541\end{array}$ & $\begin{array}{r}0 \\
67 \\
67\end{array}$ & $\begin{array}{r}1212 \\
* 1630 \\
* 1858\end{array}$ & $\begin{array}{l}1212 \\
1828 \\
2144\end{array}$ & $\begin{array}{l}1236 \\
2194 \\
2057\end{array}$ & na & $\begin{array}{l}13.64 \\
14.87 \\
14.62\end{array}$ & $\begin{array}{l}12 \\
12.71 \\
13\end{array}$ & $\begin{array}{l}0 \\
0 \\
0\end{array}$ \\
\hline $\begin{array}{l}\text { 05-Mar-80 } \\
\text { 12-Mar-80 } \\
19-M a r-80\end{array}$ & $\begin{array}{l}1250 \\
1250 \\
1250\end{array}$ & $\begin{array}{l}626 \\
644 \\
724\end{array}$ & $\begin{array}{r}400 \\
400 \\
* 737\end{array}$ & $\begin{array}{r}2276 \\
* 2294 \\
* 2711\end{array}$ & $\begin{array}{l}2276 \\
2187 \\
2187\end{array}$ & $\begin{array}{l}2508 \\
3439 \\
3001\end{array}$ & $\begin{array}{c}16.00 \\
16.63 \\
\text { na }\end{array}$ & $\begin{array}{l}16.17 \\
16.45 \\
16.24\end{array}$ & $\begin{array}{l}13 \\
13 \\
13\end{array}$ & $\begin{array}{l}0 \\
0 \\
1.29\end{array}$ \\
\hline $\begin{array}{l}\text { 26-Mar-80 } \\
02-A p r-80 \\
09-A p r-80 \\
16-A p r-80 \\
\text { 23-Apr-80 }\end{array}$ & $\begin{array}{l}2750 \\
2750 \\
2750 \\
2750 \\
2750\end{array}$ & $\begin{array}{r}26 \\
62 \\
-313 \\
-295 \\
-432\end{array}$ & $\begin{array}{r}0 \\
-150 \\
-150 \\
-150 \\
*-61\end{array}$ & $\begin{array}{r}2776 \\
* 2662 \\
* 2286 \\
* 2305 \\
* 2257\end{array}$ & $\begin{array}{l}2776 \\
2663 \\
2170 \\
2108 \\
1700\end{array}$ & $\begin{array}{l}2660 \\
2262 \\
2386 \\
2276 \\
2555\end{array}$ & $\begin{array}{c}17.00 \\
\text { na } \\
\text { na }\end{array}$ & $\begin{array}{l}17.78 \\
19.39 \\
19.04 \\
18.35 \\
17.56\end{array}$ & $\begin{array}{l}13 \\
13 \\
13 \\
13 \\
13\end{array}$ & $\begin{array}{l}3 \\
3 \\
3 \\
3 \\
3\end{array}$ \\
\hline $\begin{array}{l}30-A p r-80 \\
07-\text { May-80 } \\
14-\text { May-80 } \\
21 \text {-May-80 }\end{array}$ & $\begin{array}{l}1375 \\
1375 \\
1375 \\
1375\end{array}$ & $\begin{array}{l}-588 \\
-802 \\
-821 \\
-854\end{array}$ & $\begin{array}{r}0 \\
151 \\
151 \\
151\end{array}$ & $\begin{array}{r}787 \\
724 \\
* 705 \\
* 672\end{array}$ & $\begin{array}{r}787 \\
327 \\
170 \\
0\end{array}$ & $\begin{array}{r}1916 \\
562 \\
207 \\
99\end{array}$ & $\begin{array}{l}14.50 \\
13.50 \\
11.00\end{array}$ & $\begin{array}{l}15.12 \\
12.96 \\
10.85 \\
10.71\end{array}$ & $\begin{array}{l}13 \\
13 \\
13 \\
13\end{array}$ & $\begin{array}{l}3 \\
2.57 \\
0 \\
0\end{array}$ \\
\hline $\begin{array}{l}\text { 28-May-80 } \\
\text { 04-Jun-80 } \\
11 \text {-Jun-80 } \\
\text { 18-Jun-80 }\end{array}$ & $\begin{array}{l}100 \\
100 \\
100 \\
100\end{array}$ & $\begin{array}{r}0 \\
0 \\
-6 \\
0\end{array}$ & $\begin{array}{l}0 \\
0 \\
0 \\
0\end{array}$ & $\begin{array}{r}100 \\
100 \\
\star 94 \\
* 100\end{array}$ & $\begin{array}{r}100 \\
31 \\
0 \\
0\end{array}$ & $\begin{array}{r}307 \\
105 \\
32 \\
120\end{array}$ & na & $\begin{array}{r}9.46 \\
10.74 \\
9.68 \\
8.99\end{array}$ & $\begin{array}{l}13 \\
12 \\
12 \\
11.14\end{array}$ & $\begin{array}{l}0 \\
0 \\
0 \\
0\end{array}$ \\
\hline $\begin{array}{l}\text { 25-Jun-80 } \\
02-J u l-80 \\
09-J u 1-80\end{array}$ & $\begin{array}{l}100 \\
100 \\
100\end{array}$ & $\begin{array}{l}0 \\
0 \\
0\end{array}$ & $\begin{array}{r}0 \\
0 \\
*-27\end{array}$ & $\begin{array}{r}100 \\
* 100 \\
* 73\end{array}$ & $\begin{array}{l}100 \\
128 \\
100\end{array}$ & $\begin{array}{l}44 \\
74 \\
17\end{array}$ & $\begin{array}{l}\text { na } \\
\text { na } \\
\text { na }\end{array}$ & $\begin{array}{l}9.08 \\
9.41 \\
9.26\end{array}$ & $\begin{array}{l}11 \\
11 \\
11\end{array}$ & $\begin{array}{l}0 \\
0 \\
0\end{array}$ \\
\hline $\begin{array}{l}\text { 16-Jul-80 } \\
23-J u l-80 \\
30-J u l-80 \\
\text { 06-Aug-80 } \\
13-A u g-80\end{array}$ & $\begin{array}{l}75 \\
75 \\
75 \\
75 \\
75\end{array}$ & $\begin{array}{r}0 \\
0 \\
33 \\
57 \\
159\end{array}$ & $\begin{array}{l}0 \\
0 \\
0 \\
0 \\
0\end{array}$ & $\begin{array}{r}75 \\
75 \\
108 \\
132 \\
234\end{array}$ & $\begin{array}{r}75 \\
64 \\
125 \\
75 \\
93\end{array}$ & $\begin{array}{r}121 \\
45 \\
343 \\
570 \\
117\end{array}$ & $\begin{array}{l}\text { na } \\
\text { na } \\
\text { na } \\
\text { na }\end{array}$ & $\begin{array}{l}8.98 \\
8.68 \\
8.98 \\
9.60 \\
8.85\end{array}$ & $\begin{array}{l}11 \\
11 \\
10.57 \\
10 \\
10\end{array}$ & $\begin{array}{l}0 \\
0 \\
0 \\
0 \\
0\end{array}$ \\
\hline
\end{tabular}




\begin{tabular}{|c|c|c|c|c|c|c|c|c|c|c|}
\hline \multirow[b]{2}{*}{ Date } & \multicolumn{6}{|c|}{ BORROWED RESERVES } & \multicolumn{2}{|c|}{ FUNDS RATE } & \multicolumn{2}{|c|}{ DISCOUNT RATE } \\
\hline & $\begin{array}{c}\text { Initial } \\
\text { Average } \\
\text { Target }\end{array}$ & $\begin{array}{c}\text { Total } \\
\text { Reserve } \\
\text { Gap }\end{array}$ & $\begin{array}{l}\text { Judgmental } \\
\text { Adjustments }\end{array}$ & $\begin{array}{c}\text { Revised } \\
\text { Average } \\
\text { Target }\end{array}$ & $\begin{array}{l}\text { Target for } \\
\text { Remaining } \\
\text { Weeks }\end{array}$ & $\begin{array}{l}\text { Actual } \\
\text { Borrowing }\end{array}$ & $\begin{array}{l}\text { Midpoint } \\
\text { Expected } \\
\text { Funds Rate }\end{array}$ & $\begin{array}{c}\text { Actual } \\
\text { Funds } \\
\text { Rate }\end{array}$ & $\begin{array}{l}\text { Discount } \\
\text { Rate }\end{array}$ & Surcharge \\
\hline $\begin{array}{l}\text { 20-Aug-80 } \\
27-A u g-80 \\
03-\text { Sep-80 } \\
10-\text { Sep-80 } \\
17-\text { Sep-80 }\end{array}$ & $\begin{array}{l}75 \\
75 \\
75 \\
75 \\
75\end{array}$ & $\begin{array}{l}128 \\
282 \\
362 \\
285 \\
380\end{array}$ & $\begin{array}{r}0 \\
0 \\
0 \\
150 \\
150\end{array}$ & $\begin{array}{l}203 \\
357 \\
437 \\
510 \\
605\end{array}$ & $\begin{array}{l}203 \\
425 \\
534 \\
409 \\
755\end{array}$ & $\begin{array}{r}83 \\
500 \\
1150 \\
537 \\
1213\end{array}$ & $\begin{array}{c}\text { na } \\
11.00\end{array}$ & $\begin{array}{r}9.35 \\
10.03 \\
10.47 \\
10.22 \\
10.64\end{array}$ & $\begin{array}{l}10 \\
10 \\
10 \\
10 \\
10\end{array}$ & $\begin{array}{l}0 \\
0 \\
0 \\
0 \\
0\end{array}$ \\
\hline $\begin{array}{l}\text { 24-Sep-80 } \\
01-\text { Oct-80 } \\
08-\text { Oct-80 } \\
15-\text { Oct-80 } \\
22-\text { Oct-80 }\end{array}$ & $\begin{array}{l}750 \\
750 \\
750 \\
750 \\
750\end{array}$ & $\begin{array}{l}382 \\
495 \\
323 \\
442 \\
438\end{array}$ & $\begin{array}{r}0 \\
0 \\
200 \\
200 \\
200\end{array}$ & $\begin{array}{l}1132 \\
1245 \\
1273 \\
1392 \\
1388\end{array}$ & $\begin{array}{l}1132 \\
1210 \\
1036 \\
1228 \\
1328\end{array}$ & $\begin{array}{l}1384 \\
1873 \\
1248 \\
1107 \\
1203\end{array}$ & $\begin{array}{l}11.88 \\
12.00 \\
12.75\end{array}$ & $\begin{array}{l}10.85 \\
12.38 \\
12.59 \\
12.64 \\
12.55\end{array}$ & $\begin{array}{l}10 \\
10.86 \\
11 \\
11 \\
11\end{array}$ & $\begin{array}{l}0 \\
0 \\
0 \\
0 \\
0\end{array}$ \\
\hline $\begin{array}{l}\text { 29-Oct-80 } \\
05-\text { Nov-80 } \\
12-\text { Nov-80 } \\
19-\text { Nov-80 }\end{array}$ & $\begin{array}{l}1300 \\
1300 \\
1300 \\
1300\end{array}$ & $\begin{array}{l}209 \\
201 \\
219 \\
300\end{array}$ & $\begin{array}{r}0 \\
0 \\
100 \\
150\end{array}$ & $\begin{array}{l}1509 \\
1501 \\
1619 \\
1750\end{array}$ & $\begin{array}{l}1509 \\
1521 \\
1579 \\
1615\end{array}$ & $\begin{array}{l}1440 \\
1878 \\
2067 \\
1979\end{array}$ & $\begin{array}{l}13.63 \\
15.00\end{array}$ & $\begin{array}{l}13.17 \\
13.99 \\
14.65 \\
15.22\end{array}$ & $\begin{array}{l}11 \\
11 \\
11 \\
11.43\end{array}$ & $\begin{array}{l}0 \\
0 \\
0 \\
0.86\end{array}$ \\
\hline $\begin{array}{l}\text { 26-Nov-80 } \\
03-\mathrm{Dec}-80 \\
10-\mathrm{Dec}-80 \\
17-\mathrm{Dec}-80\end{array}$ & $\begin{array}{l}1500 \\
1500 \\
1500 \\
1500\end{array}$ & $\begin{array}{l}403 \\
341 \\
261 \\
210\end{array}$ & $\begin{array}{r}0 \\
170 \\
170 \\
170\end{array}$ & $\begin{array}{l}1903 \\
2011 \\
1931 \\
1880\end{array}$ & $\begin{array}{l}1903 \\
1960 \\
1766 \\
1629\end{array}$ & $\begin{array}{l}2215 \\
2142 \\
1786 \\
1505\end{array}$ & $\begin{array}{l}17.50 \\
19.50 \\
19.50\end{array}$ & $\begin{array}{l}17.43 \\
17.72 \\
18.82 \\
19.83\end{array}$ & $\begin{array}{l}12 \\
12 \\
12.86 \\
13\end{array}$ & $\begin{array}{l}2 \\
2 \\
2.86 \\
3\end{array}$ \\
\hline $\begin{array}{l}\text { 24-Dec-80 } \\
31-D e c-80 \\
07-J a n-81 \\
\text { 14-Jan-81 }\end{array}$ & $\begin{array}{l}1500 \\
1500 \\
1500 \\
1500\end{array}$ & $\begin{array}{r}0 \\
-57 \\
-177 \\
-170\end{array}$ & $\begin{array}{l}0 \\
0 \\
0 \\
0\end{array}$ & $\begin{array}{l}1500 \\
1443 \\
1323 \\
1330\end{array}$ & $\begin{array}{r}1500 \\
1374 \\
1008 \\
927\end{array}$ & $\begin{array}{l}1650 \\
1627 \\
1117 \\
1333\end{array}$ & $\begin{array}{c}\text { na } \\
17.50\end{array}$ & $\begin{array}{l}19.44 \\
18.45 \\
20.06 \\
19.64\end{array}$ & $\begin{array}{l}13 \\
13 \\
13 \\
13\end{array}$ & $\begin{array}{l}3 \\
3 \\
3 \\
3\end{array}$ \\
\hline $\begin{array}{l}\text { 21-Jan-81 } \\
\text { 28-Jan-81 } \\
04-F e b-81\end{array}$ & $\begin{array}{l}1500 \\
1500 \\
1500\end{array}$ & $\begin{array}{l}-301 \\
-332 \\
-414\end{array}$ & $\begin{array}{r}0 \\
0 \\
280\end{array}$ & $\begin{array}{l}1199 \\
1168 \\
1366\end{array}$ & $\begin{array}{l}1199 \\
1150 \\
1100\end{array}$ & $\begin{array}{l}1205 \\
1793 \\
1201\end{array}$ & 17.50 & $\begin{array}{l}19.35 \\
18.12 \\
17.19\end{array}$ & $\begin{array}{l}13 \\
13 \\
13\end{array}$ & $\begin{array}{l}3 \\
3 \\
3\end{array}$ \\
\hline $\begin{array}{l}\text { 11-Feb-81 } \\
18 \text {-Feb-81 } \\
25-F e b-81 \\
25 \text {-Feb-81 } \\
\text { 04-Mar-81 }\end{array}$ & $\begin{array}{l}1300 \\
1300 \\
1300 \\
1300 \\
1300\end{array}$ & $\begin{array}{l}-169 \\
-327 \\
-351 \\
-351 \\
-484\end{array}$ & $\begin{array}{r}0 \\
0 \\
0 \\
166 \\
\star 414\end{array}$ & $\begin{array}{r}1131 \\
973 \\
949 \\
1115 \\
1230\end{array}$ & $\begin{array}{r}1131 \\
926 \\
769 \\
1100 \\
1020\end{array}$ & $\begin{array}{l}1113 \\
1145 \\
1642 \\
1642 \\
1299\end{array}$ & 17.00 & $\begin{array}{l}16.51 \\
15.81 \\
14.96 \\
14.96 \\
15.73\end{array}$ & $\begin{array}{l}13 \\
13 \\
13 \\
13 \\
13\end{array}$ & $\begin{array}{l}3 \\
3 \\
3 \\
3 \\
3\end{array}$ \\
\hline $\begin{array}{l}\text { 11-Mar-81 } \\
\text { 18-Mar-81 } \\
\text { 25-Mar-81 } \\
\text { 01-Apr-81 }\end{array}$ & $\begin{array}{l}1300 \\
1300 \\
1300 \\
1300\end{array}$ & $\begin{array}{l}-481 \\
-472 \\
-349 \\
-402\end{array}$ & $\begin{array}{l}0 \\
0 \\
0 \\
0\end{array}$ & $\begin{array}{l}819 \\
828 \\
951 \\
898\end{array}$ & $\begin{array}{r}819 \\
848 \\
1131 \\
1162\end{array}$ & $\begin{array}{r}768 \\
774 \\
888 \\
1464\end{array}$ & $\begin{array}{c}15.00 \\
\text { na } \\
15.00\end{array}$ & $\begin{array}{l}15.53 \\
14.13 \\
13.48 \\
14.93\end{array}$ & $\begin{array}{l}13 \\
13 \\
13 \\
13\end{array}$ & $\begin{array}{l}3 \\
3 \\
3 \\
3\end{array}$ \\
\hline $\begin{array}{l}\text { 08-Apr-81 } \\
\text { 15-Apr-81 } \\
\text { 22-Apr-81 } \\
\text { 29-Apr-81 }\end{array}$ & $\begin{array}{l}1150 \\
1150 \\
1150 \\
1150\end{array}$ & $\begin{array}{r}0 \\
33 \\
97 \\
-10\end{array}$ & $\begin{array}{l}0 \\
0 \\
0 \\
0\end{array}$ & $\begin{array}{l}1150 \\
1183 \\
1247 \\
1140\end{array}$ & $\begin{array}{l}1150 \\
1282 \\
1480 \\
1667\end{array}$ & $\begin{array}{r}887 \\
1142 \\
863 \\
2278\end{array}$ & na & $\begin{array}{l}15.43 \\
15.33 \\
15.55 \\
16.28\end{array}$ & $\begin{array}{l}13 \\
13 \\
13 \\
13\end{array}$ & $\begin{array}{l}3 \\
3 \\
3 \\
3\end{array}$ \\
\hline $\begin{array}{l}\text { 06-May-81 } \\
13-\text { May-81 } \\
\text { 20-May-81 }\end{array}$ & $\begin{array}{l}1150 \\
1150 \\
1150\end{array}$ & $\begin{array}{l}552 \\
374 \\
389\end{array}$ & $\begin{array}{l}250 \\
484 \\
484\end{array}$ & $\begin{array}{l}1953 \\
2008 \\
2023\end{array}$ & $\begin{array}{l}1953 \\
1777 \\
1863\end{array}$ & $\begin{array}{l}2471 \\
1733 \\
1975\end{array}$ & $\begin{array}{l}\text { na } \\
19.00 \\
19.00\end{array}$ & $\begin{array}{l}18.91 \\
18.21 \\
18.89\end{array}$ & $\begin{array}{l}13.29 \\
14 \\
14\end{array}$ & $\begin{array}{l}3.29 \\
4 \\
4\end{array}$ \\
\hline $\begin{array}{l}\text { 27-May-81 } \\
03-J u n-81 \\
10-J u n-81 \\
17-J u n-81\end{array}$ & $\begin{array}{l}2100 \\
2100 \\
2100 \\
2100\end{array}$ & $\begin{array}{r}0 \\
6 \\
-63 \\
-60\end{array}$ & $\begin{array}{r}0 \\
206 \\
206 \\
206\end{array}$ & $\begin{array}{l}2100 \\
2312 \\
2243 \\
2247\end{array}$ & $\begin{array}{l}2100 \\
2108 \\
2048 \\
1902\end{array}$ & $\begin{array}{l}2923 \\
1954 \\
2207 \\
1895\end{array}$ & $\begin{array}{c}20.00 \\
20.00 \\
\mathrm{na}\end{array}$ & $\begin{array}{l}18.71 \\
18.40 \\
19.33 \\
19.10\end{array}$ & $\begin{array}{l}14 \\
14 \\
14 \\
14\end{array}$ & $\begin{array}{l}4 \\
4 \\
4 \\
4\end{array}$ \\
\hline $\begin{array}{c}\text { 24-Jun-81 } \\
01-J u l-81 \\
08-J u l-81\end{array}$ & $\begin{array}{l}2100 \\
2100 \\
2100\end{array}$ & $\begin{array}{l}-179 \\
-134 \\
-164\end{array}$ & $\begin{array}{l}-300 \\
-132 \\
-132\end{array}$ & $\begin{array}{l}1621 \\
1834 \\
1804\end{array}$ & $\begin{array}{l}1621 \\
1599 \\
1372\end{array}$ & $\begin{array}{l}2305 \\
1735 \\
1868\end{array}$ & 18.50 & $\begin{array}{l}19.20 \\
18.84 \\
19.93\end{array}$ & $\begin{array}{l}14 \\
14 \\
14\end{array}$ & $\begin{array}{l}4 \\
4 \\
4\end{array}$ \\
\hline $\begin{array}{l}15-J u l-81 \\
22-J u l-81 \\
29-J u l-81\end{array}$ & $\begin{array}{l}1500 \\
1500 \\
1500\end{array}$ & $\begin{array}{r}0 \\
32 \\
-8\end{array}$ & $\begin{array}{l}0 \\
0 \\
0\end{array}$ & $\begin{array}{l}1500 \\
1532 \\
1492\end{array}$ & $\begin{array}{l}1500 \\
1651 \\
1450\end{array}$ & $\begin{array}{l}1294 \\
1730 \\
1978\end{array}$ & $\begin{array}{l}18.50 \\
18.00\end{array}$ & $\begin{array}{l}18.76 \\
19.05 \\
18.54\end{array}$ & $\begin{array}{l}14 \\
14 \\
14\end{array}$ & $\begin{array}{l}4 \\
4 \\
4\end{array}$ \\
\hline $\begin{array}{l}\text { 05-Aug-81 } \\
12-A u g-81 \\
19-A u g-81\end{array}$ & $\begin{array}{l}1500 \\
1500 \\
1500\end{array}$ & $\begin{array}{l}-155 \\
-139 \\
-158\end{array}$ & $\begin{array}{r}0 \\
-76 \\
-76\end{array}$ & $\begin{array}{l}1345 \\
1285 \\
1266\end{array}$ & $\begin{array}{l}1345 \\
1370 \\
1409\end{array}$ & $\begin{array}{l}1118 \\
1271 \\
1400\end{array}$ & $\begin{array}{c}\text { na } \\
\text { na } \\
18.00\end{array}$ & $\begin{array}{l}18.25 \\
18.29 \\
18.19\end{array}$ & $\begin{array}{l}14 \\
14 \\
14\end{array}$ & $\begin{array}{l}4 \\
4 \\
4\end{array}$ \\
\hline $\begin{array}{l}\text { 26-Aug-81 } \\
02-\text { Sep-81 } \\
09-\text { Sep-81 } \\
16-\text { Sep-81 }\end{array}$ & $\begin{array}{l}1400 \\
1400 \\
1400 \\
1400\end{array}$ & $\begin{array}{l}-158 \\
-200 \\
-318 \\
-298\end{array}$ & $\begin{array}{r}0 \\
* 93 \\
* 122 \\
* 191\end{array}$ & $\begin{array}{r}1242 \\
* 1293 \\
* 1204 \\
* 1293\end{array}$ & $\begin{array}{r}1242 \\
1200 \\
995 \\
995\end{array}$ & $\begin{array}{l}1571 \\
1258 \\
1349 \\
1062\end{array}$ & $\begin{array}{c}n a \\
17.00 \\
16.50\end{array}$ & $\begin{array}{l}17.41 \\
16.89 \\
16.50 \\
16.09\end{array}$ & $\begin{array}{l}14 \\
14 \\
14 \\
14\end{array}$ & $\begin{array}{l}4 \\
4 \\
4 \\
4\end{array}$ \\
\hline $\begin{array}{l}23-\text { Sep-81 } \\
30-\text { Sep-81 } \\
07-\text { Oct-81 }\end{array}$ & $\begin{array}{l}1400 \\
1400 \\
1400\end{array}$ & $\begin{array}{l}-447 \\
-419 \\
-379\end{array}$ & $\begin{array}{l}0 \\
0 \\
0\end{array}$ & $\begin{array}{r}953 \\
981 \\
1021\end{array}$ & $\begin{array}{l}953 \\
912 \\
883\end{array}$ & $\begin{array}{r}1121 \\
1059 \\
733\end{array}$ & $\begin{array}{l}16.00 \\
15.50 \\
15.50\end{array}$ & $\begin{array}{l}15.33 \\
15.00 \\
15.46\end{array}$ & $\begin{array}{l}14 \\
14 \\
14\end{array}$ & $\begin{array}{l}3.71 \\
3 \\
3\end{array}$ \\
\hline
\end{tabular}




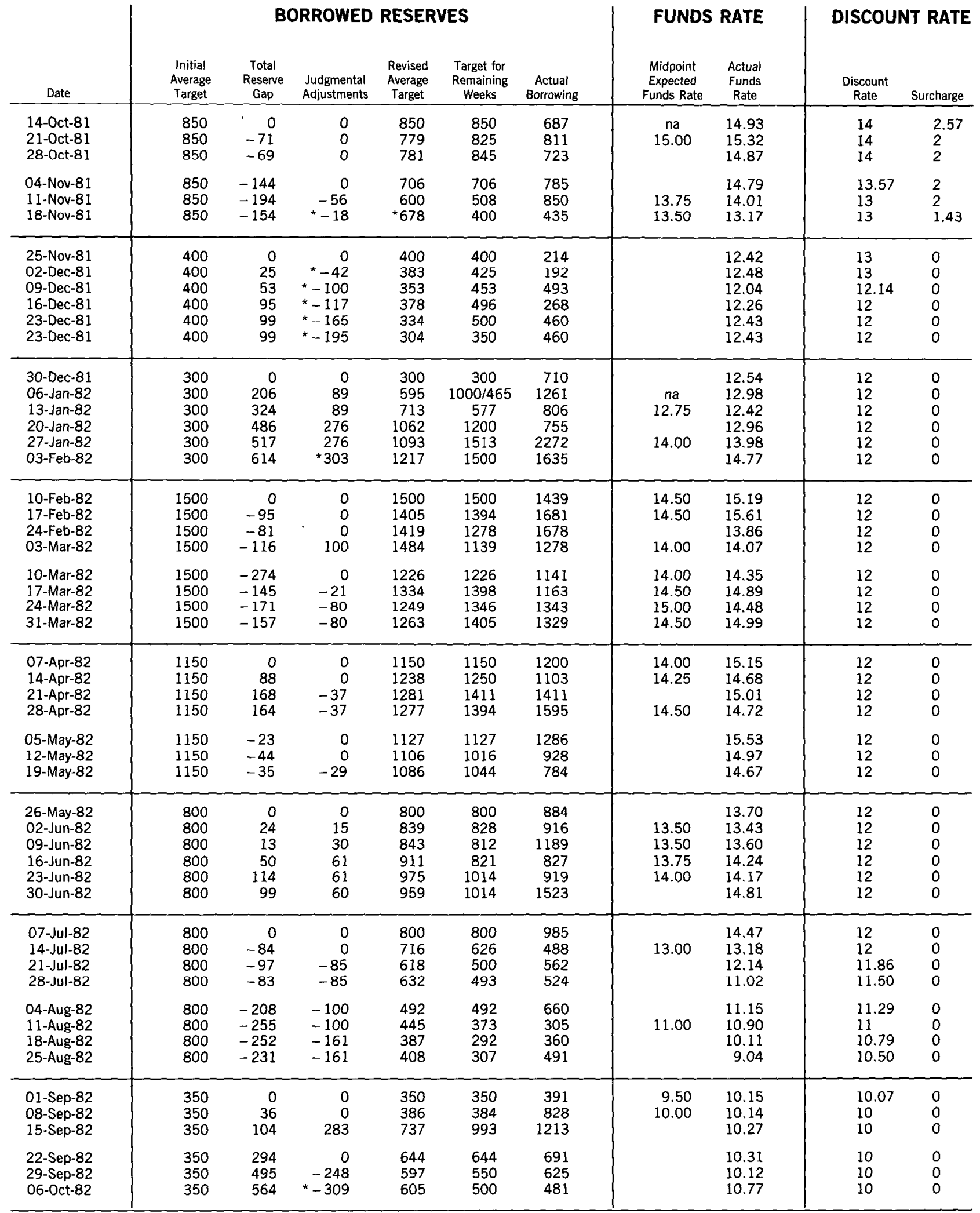




\title{
MONETARY AGGREGATES: A USER'S GUIDE
}

\author{
John R. Walter
}

The monetary aggregates are measures of the nation's money stock. The most narrowly defined monetary aggregate, $\mathrm{M} 1$, is the sum of the dollar amounts of currency and nonbank travelers checks in circulation, plus checkable deposits. M2 includes M1 plus overnight repurchase agreements, overnight Eurodollar deposits, general purpose and broker/ dealer money market fund balances, money market deposit accounts, and savings and small time deposits. M3 is the sum of M2 and large time deposits, term repurchase agreements, term Eurodollar deposits, and balances in money market funds employed solely by institutional investors. Analysts study the relationships among these monetary measures and other macroeconomic variables, such as national income, employment, interest rates, and the price level. These relationships are then used to forecast changes in economic activity, interest rates, and inflation. The Board of Governors of the Federal Reserve System defines the aggregates and calculates and reports their values.

This article explains the origin and evolution of the monetary aggregates and discusses how they are prepared and released, how they are used, and when and why they are revised. Information on the monetary base is also included.

\section{How the Monetary Aggregates Evolved}

Over the years economists have proposed many different groupings of financial assets into something called "money." No single definition of money has been universally acceptable. Two approaches have been used to define money. The first is to identify what financial assets are commonly used for certain purposes. Analysts using this approach generally include as money financial assets serving (1) as a medium of exchange, i.e., assets widely acceptable in payment for goods, services, and debts, and (2) as a store of value. A second approach to defining money is to find the groupings of financial assets the movements of which are most closely correlated with the movements of certain macroeconomic variables such as national income, employment, and prices. Both approaches have contributed to the development of the monetary aggregates constructed by the Federal Reserve. A brief chronology of the evolution of these measures is given below.
In 1944 the Board of Governors of the Federal Reserve System began reporting monthly data on two types of exchange media, (1) currency outside of banks, and (2) demand deposits at banks, i.e., non-interest-bearing deposits transferable by check or convertible into cash "on demand." It also reported the sum of these two. The Board's expressed intent in reporting the data was "to increase the information available to the public on current changes ... in the nation's money supply." In time the sum of currency outside banks and demand deposits came to be called M1, the narrowest of the Fed's monetary aggregates.

Until 1971 M1 was the only monetary aggregate for which estimates were published by the Board of Governors. In that year, however, the Board began reporting data for two additional aggregates, M2 and M3. Interest in these latter variables reflected the growing importance of the monetary aggregates in formulating monetary policy. It also reflected the view among some economists that the appropriate definition of money should include assets capable of providing a temporary store of value. Accordingly, M2 was defined to include M1 plus savings deposits at: commercial banks and time deposits at commercial banks except large negotiable certificates of deposit. Similarly M3 was defined as the sum of M2 and deposits at mutual savings banks and savings and loan associations.

In 1975, the Board began publishing data for even broader collections of financial assets, namely M4 and M5. M4 included M2 plus large negotiable certificates of deposit. M5 was the sum of M3 and large negotiable certificates of deposit.

The decade of the 1970s witnessed the development of many financial instruments. Some of the new assets were close substitutes for demand deposits, namely negotiable order of withdrawal (NOW) accounts which are interest-bearing checkable accounts, savings accounts featuring automatic transfer to checking accounts (ATS accounts), credit union share: draft accounts, and money market mutual funds with checking privileges. These new accounts began to be used as exchange media but were not counted in M1 until 1980.

The introduction of these new assets also coincided with what some economists interpreted as changes 
in the relationships between the monetary aggregates and economic variables such as income, employment, and prices. These apparent changes provided some of the Fed's motivation for modifying its definitions of the aggregates in $1980 . .^{1}$ At that time the Fed replaced its M1 definition of money with M1A and M1B. M1A was equivalent to the old M1, including only currency and demand deposits; M1B included all of M1A plus NOW and ATS balances at banks and thrifts, credit union share draft balances, and demand deposits at mutual savings banks. ${ }^{2}$ At the same time old M2 through M5 were replaced with new measures of M2 and M3. New M2 included all of M1B and a number of other assets that are easily convertible to transaction account deposits or that can be used in transactions to a limited degree. These were overnight repurchase agreements (RPs) issued by commercial banks and certain overnight Eurodollars held by nonbank U.S. residents, moncy market mutual fund shares, and savings and smalldenomination time deposits at all depository institutions. ${ }^{3}$ New M3 added to M2 large-denomination time deposits at all depository institutions and term RPs at commercial banks and savings and loan associations.

In January 1982 the Board of Governors stopped reporting $\mathrm{M} 1 \mathrm{~A}$ and redesignated $\mathrm{M} 1 \mathrm{~B}$ as $\mathrm{M} 1$. Since then the definitions have been modified only slightly. Table I shows the current magnitudes of M1, $\mathrm{M} 2$, and $\mathrm{M} 3$.

\section{Monetary Base}

The monetary base is composed of currency held by the public and in vaults of depository institutions, plus reserves of depository institutions. In 1968 the Federal Reserve Bank of St. Louis began publishing figures on the monetary base. In 1979 the Board of Governors of the Federal Reserve System also began publishing data on a somewhat different version of the monetary base.

The base can be viewed as the foundation upon which the superstructure of deposits is erected. An increase in the reserves component of the base allows the system of depository institutions to expand deposits. Initially, an increase in reserves-resulting from open market operations or loans by the Fed-

\footnotetext{
1 See Board of Governors (June 1976) and Board of Governors (January 1979), p. 24.

2 M1A excluded demand deposits held by foreign commercial banks and foreign official institutions while old M1 did not.

3 For a thorough discussion of RPs see Stephen A. Lumpkin's article "Repurchase and Reverse Repurchase Agreements" in Cook and Rowe (1986), pp. 65-80.
}

leads to an increase in "excess" reserves, that is, reserves beyond the amount needed to meet reserve requirements at depository institutions. These institutions use the excess reserves to make loans and investments which soon become deposits. When these deposits are spent and redeposited, they create additional excess reserves and lead to the extension of more loans. Through a multiplicative process the money supply is increased by a multiple of the Fed's original addition to the monetary base. The extent to which the money stock increases upon an increase in the monetary base depends on the percentages of required and excess reserves held by depository institutions and on the public's holdings of cash relative to deposits. ${ }^{4}$

As noted above, the Board of Governors' and the St. Louis Federal Reserve Bank's estimates of the monetary base differ, and do so in three respects. First, the Board and St. Louis adjust the base differently to cleanse it of changes that are simply the result of changes in reserve requirements. ${ }^{5}$ Second, the Board and St. Louis account for vault cash differently. Third, they seasonally adjust their estimates differently. ${ }^{6}$

\section{Preparation and Release of Monetary Data}

The Board of Governors constructs its estimates of the monetary aggregates from information supplied by depository institutions, the U.S. Treasury, money market mutual funds, New York State investment companies, nonbank issuers of travelers checks, and foreign central banks. Some of these institutions report every week, others report less frequently. Some report in an abbreviated form not available to larger institutions. To produce weekly and monthly estimates of the aggregates, the Board estimates missing data where detail or frequency of reporting

\footnotetext{
4 Humphrey (1987) describes the theory of deposit expansion and its history. Most introductory level college money and banking texts provide a basic discussion of how monetary actions of the Fed affect the base and the money stock. Burger (1971) goes into great detail.

$s$ For example, when the reserve requirement against business time deposits with maturities of $2-1 / 2$ to $3-1 / 2$ years was dropped in April 1983, the amount of reserves banks were required to hold declined by $\$ 80$ million. In order to prevent a corresponding increase in excess reserves the Fed concurrently withdrew this $\$ 80$ million through open market operations, leading to an identical decline in the monetary base. The Board of Governors and the Federal Rescrve Bank of St. Louis then eliminated this $\$ 80$ million decline in their adjusted monetary base data.

6 Burger (1979) discusses the causes of the differences between the Board of Governors' and St. Louis' monetary base estimates.
} 
Table I

\section{COMPONENTS OF THE MONETARY AGGREGATES AND MONETARY BASE AND THEIR LEVELS}

\section{August 1988}

Billions of dollars

M1

Currency

Travelers checks

Demand deposits

Other checkable deposits

M2

M1

Overnight RPs

Overnight Eurodollars

MMF balances (general purpose and broker/dealer)

MMDAs

Savings deposits

Small time deposits

M3

M2

Large time deposits

Term RPs

Term Eurodollars

MMF balances (institution only)

\section{Monetary Base}

Currency

Reserves
782.5

207.2

7.2

290.0

278.1

3032.0

782.5

64.9

15.8

231.2

517.1

433.8

985.2

3847.3

3032.0

514.7

121.0

102.4

84.0

271.2

207.2

61.1

Sources: Data for M1, M2, M3 and their components are from Board of Governors of the Federal Reserve System H.6 release, "Money Stock, Liquid Assets, and Debt Measures," dated October 6, 1988. Data for Monetary Base are from Board of Governors of the Federal Reserve System H.3 release "Aggregate Reserves of Depository Institutions and the Monetary Base," dated October 6, 1988. The Currency figure shown below Monetary Base is from H.6 while the Reserves figure is from H.3.

Explanation: $M 2$ and $M 3$ both differ from the sums of their components because these aggregates are seasonally adjusted by adjusting the non-M1 components of $M 2$ and the non-M2 components of $M 3$ as blocks. Several of these components are not reported in seasonally adjusted form while those that are have been adjusted individually. Monetary Base differs from its components because the currency component the Board uses in its Monetary Base computation includes some adjustments excluded from the $H G$ currency figure. The Boaro does not publish the currency portion of Monetary Base separately.

Other checkable deposits are negotiable order of withdrawal (NOW) accounts, automatic transfer service (ATS) accounts, credit union share draft accounts, and demand deposits at thrift institutions.

- $R P_{\mathrm{S}}$, repurchase agreements, are loan arrangements in which the borrower sells the lender securities with an agreement to repurchase them at a future date.

Eurodollars are dollar-denominated deposits issued to U.S. residents by forcign branches of U.S. banks worldwide.

MMF, money market mutual funds, are funds investing in money market instruments, offered by investment companies.

MMDA, money market deposit accounts, are savings deposits on which only a limited number of checks can be drawn each month.

Savings deposits are liabilities of depository institutions that do not specify a date of withdrawal or a time period after which deposited funds may be withdrawn, although depository institutions must reserve the right to require at least seven days written notice before withdrawal of savings deposits.

Time deposits are liabilities of depository institutions payable on a specified date, or after a specified period of time or notice period, which in all cases may not be less than seven days following the date of deposit.

Term, as in Term RPs and Term Eurodollars, means maturities of greater than one day.

The Reserves component of Monetary Base is total reserves of depository institutions with Federal Reserve Banks plus vault cash used to satisfy reserve requirements and is adjusted for reserve requirement changes.

For a detailed description of each of the components of $M 1, M 2$, and $M 3$ see any recent H.6 release or footnotes to the table entitled "Money Stock, Federal Reserve Bulletin. For a detailed description of the Reserves component of Monetary Base see the footnotes to the H.3 release, or footnotes to the table entitled "Reserves and Borrowings, Depository Institutions" in the statistical section of a recent Federal Reserve Bulletin. The Federal Reserve Bank of Richmond's Instruments of the Money Market includes a chapter for each of the major money market instruments, including chapter for each of the major money
Eurodollars, RPS, and MMF, listed above.

The Federal Reserve, in its $H .6$ release and in the tables of its Federal Resenve Bulletin, publishes estimates of liquid assets and total debt of nonfinancial sectors with the monetary aggregates even though these are not considered monetary aggregates. The liquid assets measure is called $L$ and is made up of $M 3$ plus U.S. savings bonds, short-term Treasury securities, commercial paper, and bankers acceptances. The aggregate labeled "Debt" includes the debt of the U.S. government, state and local governments, and private nonfinancial sectors. L first appeared in the Federal Resenve Bulletin in 1980, with Debt following in 1984. Items in $L$ and Debt fall outside of the category of assets that most economists would call money. are lacking. Table II lists, by component, sources of data used by the Board to calculate the monetary aggregates.

The Board of Governors reports figures for M1, M2, and M3 each week (usually on Thursday afternoon at 4:30 eastern time). Reported values are weekly averages of daily figures for the week ending ren days earlier. The Board publishes both seasonally adjusted and not seasonally adjusted data. Revisions of the seasonally adjusted aggregates can be large due to changing seasonal patterns over time. ${ }^{7}$

7 For a discussion of the difficulties of seasonal adjustment see Hein and Ott (1983).
The Board of Governors releases its most recent estimates of the monetary base every two weeks. These figures are two-week averages of daily figures for the two weeks ending eight days earlier. The Board publishes a seasonally adjusted monetary base figure adjusted for changes in reserve requirements, a not seasonally adjusted base figure adjusted for changes in reserve requirements, and a not seasonally adjusted figure not adjusted for reserve requirement changes. The St. Louis Federal Reserve Bank also releases a new estimate of the average monetary base every two weeks. It provides only a base figure adjusted for reserve requirement changes and for seasonal change. 
Table II

\section{SOURCES OF DATA USED BY THE BOARD OF GOVERNORS IN THE ESTIMATION OF THE MONETARY AGGREGATES AND THE MONETARY BASE}

M1

Currency

Nonbank travelers checks

Demand deposits and

Other checkable deposits

M2

M1

Overnight repurchase agreements

Overnight Eurodollars

Money market mutual fund (MMF) balances (general purpose and broker/dealer)

Money market deposit accounts (MMDAs)

Savings deposits

Small time deposits

M3

M2

Large time deposits

Term RPs

Term Eurodollars

MMF balances (institution only)

Monetary Base

Currency

Reserves
Currency and coin in the hands of the nonbank public.

Travelers checks issued by institutions other than banks. Included in M1 because they can be used directly for purchases.

Checkable deposits including regular noninterest-bearing checking accounts, NOW balances, ATS balances, and credit union share draft balances.

Overnight and continuing contract repurchase agreements (RPs) issued by commercial banks. Included in $M 2$ because they are generally considered short-term investments used in managing demand deposit balances.

Overnight Eurodollars issued to U.S. residents by foreign branches of U.S. banks worldwide. Short-term investments like RPs.

Often checkable, but included in M2 rather than $M 1$ because turnover rates are more like savings instruments than transactions instruments.

Limited check writing features and turnover rates like savings rather than transactions accounts cause Fed to include this asset in M2 rather than $\mathrm{M} 1$.

Passbook and telephone transfer accounts.

Time deposits at depository institutions with denominations less than $\$ 100,000$. Includes RPs with denominations less than $\$ 100,000$.

Time deposits at depository institutions with denominations of $\$ 100,000$ or more. Held largely by institutions.

Denominations $\$ 100,000$ or greater with more than one day maturity. Held largely by institutions rather than individuals.

More than one day maturity, held largely by institutions rather than individuals.

Balances held by institutions rather than individuals.

Currency and coin in the hands of the nonbank public plus currency and coin in bank vaults not used to satisfy reserve requirements.

Reserves of depository institutions held with Federal Reserve Banks plus vault cash used to satisfy reserve requirements.
Consolidated Statement of Condition of Al Federal Reserve Banks (H.4.I)-weekly; vault cash data from Report of Transaction Accounts, Other Deposits and Vault Cash (FR 2900) weekly, and Quarterly Report of Selected Deposits, Vault Cash, and Reservable Liabilities (FR 2910Q).

Report of Travelers Checks Outstanding (FR 2054)-monthly

FR 2900; FR 2910Q; Reports of Condition and Income (Call Reports)-quarterly; internal Federal Reserve float data; Weekly Report of Assets and Liabilities for Large Banks (FR 2416).

Report of Selected Borrowings (FR 2415)weekly; Annual Report of Repurchase Agreements (FR 2090A); Weekly Report of Assets of Money Market Mutual Funds (FR 2051A); Weekly Report of Assets for Selected Money Market Mutual Funds (FR 2051C).

Report of Selected Deposits in Foreign Branches Held by U.S. Residents (FR 2050)weekly; FR 2051A; FR2051C.

Investment Company Institute $(\mathrm{ICl})$ gathers FR 2051A and FR 2051C for Fed covering all MMFs.

FR 2900; FR 2910Q; Call Reports.

FR 2900; FR 2910Q; Call Reports; FR 2416. FR 2900; FR 2910Q; Call Reports; Monthly Survey of Selected Deposits and Other Accounts (FR 2042); Report of Repurchase Agreements on U.S. Government and Federal Agency Securities (FR 20900)-quarterly; FR 2090A.

FR 2900; FR 2910Q; Call Reports FR 2416; FR 2051A; FR 2051C

FR 2415; FR 2090A; Call Reports; FR 2051A; FR 2051C.

Weekly Report of Foreign Branch Liabilities to, and Custody Holdings for, U.S. Residents (FR 2077); information from Bank of Canada and Bank of England; FR 2051A; FR 2051C.

FR 2051A; FR 2051C

H.4.1; FR 2900; FR 2910Q; Call Reports.

FR 2900; H.4.1. 
The Board of Governors publishes historical series of the monetary aggregates and many of the components making up the aggregates. These series are periodically updated to reflect revisions or redefinitions of the aggregates. Both the Board and the St. Louis Fed produce historical series for the base. Table III lists the monetary aggregates and their component series as well as the monetary base and its component series available from the Board and St. Louis.

\section{How The Monetary Aggregates Data Are Used}

The Fed's legislative mandate is to set a monetary policy consistent with high employment, stable prices, and moderate longterm interest rates. In semiannual testimony to Congress, the Chairman of the Board of Governors of the Federal Reserve System reports the targets set by the Federal Open Market Committee (the Fed's monetary policymaking body) ${ }^{8}$ for growth of the monetary aggregates. The Chairman also relates these targeted growth rates to forecasted rates of unemployment, output growth, and inflation. Because of concern with the instability of the behavior of $\mathrm{M} 1$, the Federal Open Market Committee has not specified an M1 target range since 1986 , although it has continued to set target ranges for $\mathrm{M} 2$ and $\mathrm{M} 3$.

The Federal Reserve cannot directly control the quantity of money. It can, however, control

\footnotetext{
8 The President of the Federal Reserve Bank of New York is a permanent voting member of the Federal Open Market Committee while the other eleven Federal Reserve Bank presidents share four voting memberships on a rotating basis. All seven members of the Board of Governors are also permanent voting members.
}

Table II

\section{AVAILABILITY OF TIME-SERIES ON MONETARY AGGREGATES AND COMPONENTS MAKING UP MONETARY AGGREGATES}

\begin{tabular}{|c|c|c|c|c|}
\hline \multirow[b]{2}{*}{ Series } & \multicolumn{2}{|c|}{$\begin{array}{c}\text { Weekly } \\
\text { Averages } \\
\text { Available Beginning: }\end{array}$} & \multicolumn{2}{|c|}{$\begin{array}{l}\text { Monthly } \\
\text { Averages } \\
\text { Available Beginning: }\end{array}$} \\
\hline & sa & nsa & sa & nsa \\
\hline \multicolumn{5}{|l|}{ Aggregates } \\
\hline M1 & $1 / 75$ & $1 / 75$ & $1 / 59$ & $1 / 47^{\star}$ \\
\hline M2 & $1 / 81$ & $1 / 81$ & $1 / 59$ & $1 / 59$ \\
\hline M3 & $1 / 81$ & $1 / 81$ & $1 / 59$ & $1 / 59$ \\
\hline \multicolumn{5}{|l|}{ Monetary Base-Board } \\
\hline Adjusted & $1 / 59^{* *}$ & $1 / 59^{* \star}$ & $1 / 59$ & $1 / 59$ \\
\hline Unadjusted & & $1 / 59 * *$ & & $1 / 59$ \\
\hline \multicolumn{5}{|l|}{ Monetary Base-St. Louis } \\
\hline Adjusted & $1 / 72^{* *}$ & $1 / 72^{* *}$ & $1 / 50$ & $1 / 29$ \\
\hline Unadjusted & & $1 / 72^{* *}$ & & $1 / 19$ \\
\hline \multicolumn{5}{|l|}{ Components of Ms } \\
\hline Currency & $1 / 75$ & $1 / 75$ & $1 / 59$ & $1 / 47^{\star}$ \\
\hline Demand deposits & $1 / 75$ & $1 / 75$ & $1 / 59$ & $1 / 47^{*}$ \\
\hline Other checkable deposits & $1 / 75$ & $1 / 75$ & $1 / 63$ & $1 / 63$ \\
\hline Overnight RPs & & $1 / 75$ & & $11 / 69$ \\
\hline Overnight Eurodollars & & $12 / 79$ & & $2 / 77$ \\
\hline \multicolumn{5}{|l|}{ MMMF (general purpose } \\
\hline and broker/dealer) & & $2 / 80$ & & $11 / 73$ \\
\hline MMMF (institution only) & & $2 / 80$ & & $4 / 74$ \\
\hline Nonbank travelers checks & $1 / 75$ & $1 / 75$ & $1 / 59$ & $1 / 59$ \\
\hline Savings deposits & $1 / 81$ & $1 / 81$ & $1 / 59$ & $1 / 59$ \\
\hline Small time deposits & $1 / 81$ & $1 / 81$ & $1 / 59$ & $1 / 59$ \\
\hline Large time deposits & $1 / 81$ & $1 / 81$ & $1 / 59$ & $1 / 59$ \\
\hline MMDA & & $12 / 82$ & & $12 / 82$ \\
\hline Term RPs & & $1 / 75$ & & $10 / 69$ \\
\hline Term Eurodollars & & $12 / 79$ & & $1 / 59$ \\
\hline \multicolumn{5}{|l|}{ Components of Base } \\
\hline \multicolumn{5}{|l|}{ Reserves-Board } \\
\hline Adjusted & $1 / 59^{* *}$ & $1 / 59^{* *}$ & $1 / 59$ & $1 / 59$ \\
\hline Unadjusted & & $1 / 59^{* *}$ & & $1 / 59$ \\
\hline \multicolumn{5}{|l|}{ Reserves-St. Louis } \\
\hline Adjusted & & & $1 / 50$ & $1 / 47$ \\
\hline Currency_St. Louis & & $1 / 72^{* *}$ & & $1 / 50$ \\
\hline
\end{tabular}

Sources: Board of Governors of the Federal Reserve System, H.6, "Historical Money Stock Data," March 1988; Board of Governors of the Federal Reserve System, H.3, "Reserves of Depository Institutions, Historical Data," June 1988; Banking and Monetary Statistics, 1941-1970, Board of Governors of the Federal Reserve System, 1976; The Federal Reserve Bank of St. Louis.

* Data from 1/47 until 12/70 can be found in Banking and Monetary Statistics, 1941-1970, Board of Governors of the Federal Reserve System, 1976, while data for 1/59 to current are available from Board of Governors of the Federal Reserve System, H.6, "Historical Money Stock Data," March 1988. Definitions used in these two sources differ.

* Weekly data are available until $2 / 84$, after which only biweekly data are available.

sa = Seasonally adjusted

nsa $=$ Not seasonally adjusted 
variables that influence short-term interest rates, namely the quantity of reserves held by depository institutions and the monetary base, and thcrcby influence the growth rate of the aggregates. Greater provision of reserves through Federal Reserve open market purchases of securities tends to push down the federal funds rate and other short-term interest rates. Lower interest rates, in turn, help determine the quantities of the monetary aggregates demanded by the private sector. Downward pressure on federal funds and other rates makes holding money balances, which pay no or low rates of interest, less costly. The lower cost of holding money increases the quantity of money demanded. Assuming money supply equals money demand, the result is an increase in the level of monetary aggregates. Changes in the aggregates normally are followed by temporary changes in aggregate output and employment and by permanent changes in prices. ${ }^{9}$ Chart 1 illustrates the relationship between $\mathrm{M} 2$ and the price level. $\Lambda$ s is conventional in such comparisons, M2 is shown per unit of real output, i.e., is divided by real GNP, to adjust for growth in the economy. ${ }^{10}$

The monetary aggregates have been watched closely by those attempting to predict Fed policy moves. ${ }^{11}$ In periods when the Fed sought tight control of the growth rate of the aggregates, unusually fast or slow money growth has generated expectations of subsequent policy actions by the Fed to arrest or reverse these movements. In such periods, the financial markets react to the announcement of the weekly M1 figure. The announcement of a higher than expected M1 figure, for example, leads market participants to increase their estimate of the probability that the Fed will put upward pressure on the funds rate, and other short-term rates rise in reaction to these changed expectations. ${ }^{12}$

Many economists study the aggregates to improve their understanding of the links between monetary growth and changes in other macroeconomic variables. Prior to the 1980 s empirical studies generally found stable relationships between M1 growth and inflation and GNP growth. These findings were important to the Fed's decision to place more emphasis on the monetary aggregates in monetary policymaking during the 70 s and early 80 s. With the financial deregulation and disinflation of the early 1980 s

\footnotetext{
9 See Board of Governors (July 1988), pp. 419-20, and Broaddus (1988), pp. 45-49.

10 Friedman (1969), p.177.

11 Loeys (1984).

12 Walter (1988), pp. 222-25.
}

\section{M2/REAL-GNP AND GNP FIXED WEIGHT PRICE INDEX}

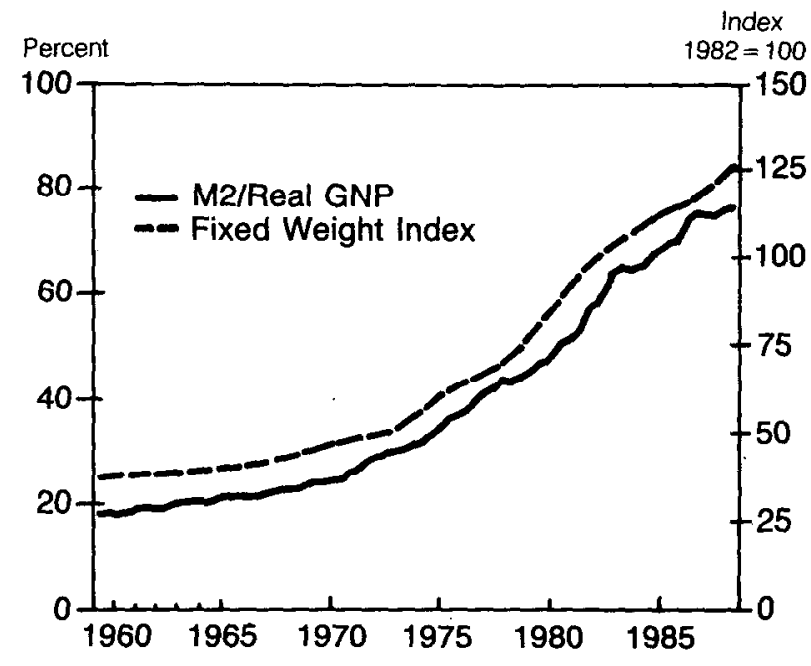

however, studies began to find that the once stable relationships between $\mathrm{M} 1$ growth and inflation and GNP growth were breaking down. These findings led the Federal Reserve in 1982 to de-emphasize M1 in its monetary policymaking process. ${ }^{13}$ Recent studies, however, suggest that changes due to disinflation and deregulation have had a smaller effect on M2 than on M1 growth, and that the relationship between M2 growth and inflation has remained fairly stable. ${ }^{14}$ In his February 1989 testimony before Congress the Chairman of the Board of Governors stated that "over the long haul there is a close relationship between money [M2] and prices." The Fed, consistent with the view that further reductions in the growth rate of $\mathrm{M} 2$ are necessary to achieve longrun price stability, reduced its target range for M2 in both 1988 and $1989 .{ }^{15}$

\section{Revisions to the Monetary Aggregates}

Major revisions to the published data on the monetary aggregates occur for four reasons. First, the data are revised as reporting or processing errors are discovered. Second, the aggregates are revised annually to incorporate "benchmark" changes. Third, the seasonally adjusted data are revised annually to incorporate new seasonal adjustment factors. Finally, the historical series are revised whenever there is a redefinition of the aggregates.

\footnotetext{
13 Friedman (1988) and Bernanke and Blinder (1988).

14 Hetzel and Mehra (1988), Mehra (1988), and Reichenstein and Elliott (1987).

15 Greenspan (April 1989) and Board of Governors (March 1989).
} 
With thousands of institutions reporting to the Federal Reserve System on a weekly basis, it is impossible for the Fed to find and correct all errors before the first release of monetary aggregate data. As errors are discovered the Board revises the data. Most revisions occur within the first month following initial release of a figure, although some can take place months later.

As noted above, to produce estimates of the monetary aggregates the Board of Governors must estimate the deposits held in financial institutions not reporting on a weekly basis. Most of these institutions do report data on a quarterly or annual basis, however. When these quarterly or annual figures become available, they provide points of reference, or "benchmarks," which the Board uses to make more accurate estimates for intervening dates. The Board makes these benchmark revisions to the aggregates each February.

The monetary aggregates are seasonally adjusted to remove those movements that tend to recur at the same time each year, such as the temporary increases in transactions balances before Christmas and before the due date for tax payments. To determine the proper seasonal adjustment factors to apply to a given month's or week's aggregates the Board normally uses data on the aggregates for three years before and three years after the month or week in question. No later data are available for the most recently released aggregates so the Board forecasts fifteen months of the data and appends it to the actual aggregate data. As time passes, the estimates of the seasonal factors can be made more accurately as forecasted data are replaced by actual data and as data errors are corrected and new benchmarks become available. Each February, the Board reestimates the seasonal factors for the data series used in the monetary aggregates and revises the seasonally adjusted data accordingly. ${ }^{16}$

As discussed earlier, the Federal Reserve changes the definitions of its aggregates from time-to-time following financial market innovations and regulatory changes that affect the way money is held. Some definitional changes are minor and produce only small revisions in the aggregates: others, such as those occurring during the early 1980s, lead to major revisions. When the Fed changes the definitions of the monetary aggregates, it revises the historical data to be consistent over the whole period of the series. (For a list of the beginning dates of various series see Table III.) Previously published data, however,

${ }^{16}$ Lawler (1977), Hein and Ott (1983), pp. 16-20, and Cook (1984), pp. 22-25. may not bear the same definitions. Thus when comparing data at different dates, users should take care to determine that the data definitions are consistent.

\section{Sources of Data}

Monetary aggregate data are available from many sources. On each Friday The Wall Street Journal publishes a table giving the money stock data released on Thursday afternoon. Historical data can be found in the Federal Reserve Bulletin, in the Board of Governor's H.6 release, in the Board's annual historical supplement to the H.6, "Historical Money Stock Data," in the Federal Reserve's Banking and Monetary Statistics, 1924-1941, Banking and Monetary Statistics, 1941-1970, and Annual Statistical Digest for years since 1970.

Historical data on the monetary base are available directly from the St. Louis Federal Reserve Bank and from the Board of Governors, or in the Board's H.3 release as well as the Board's historical supplement to the H.3, "Reserves of Depository Institutions, Historical Data." Normally, on Friday, The Wall Street Journal publishes a table including the most recent figures on the monetary base from the H.3 release.

\section{Suggestions for Further Reading}

Most college level money and banking texts discuss the monetary aggregates and the monetary base and their relationship to economic variables. James $\mathrm{N}$. Duprey's "How the Fed Defines and Measures Money" in the Spring-Summer 1982 issue of the Quarterly Review of the Federal Reserve Bank of Minneapolis, examines the aggregates and discusses their construction. "Data Sources Used In Constructing the U.S. Monetary Aggregates," a 1984 monograph by Cynthia Glassman of the Board of Governors of the Federal Reserve System, details the sources used in the estimation of the monetary aggregates. The debate among economists over the best definition of money is discussed in Alfred Broaddus's "Aggregating the Monetary Aggregates: Concepts and Issues" in the Economic Review of the Federal Reserve Bank of Richmond, November/December 1975.

The footnotes found in the Board of Governor's weekly H.6 release provide detailed definitions of the aggregates. The H.6 release also describes components included in each of the aggregates and reports their estimated levels over time.

The February 1980 Federal Reserve Bulletin article "The Redefined Monetary Aggregates" by Thomas Simpson, describes the events and intellectual forces that led the Fed to redefine its aggregates in 1980 
and specifies how the redefinition was accomplished. This article includes time series charts showing the growth of the pre-1980 aggregates and the post-1980 aggregates.

A Monetary History of the United States, 18671960 , by Milton Friedman and Anna Schwartz provides a seminal discussion of how changes in growth of the money stock have affected the American economy. The authors discuss and make use of the Fed's monetary aggregates throughout much of the book. Monetary Statistics of the United States, also by Friedman and Schwartz, provides estimates of the quantity of money for the period 1867-1968 and discusses sources and methods of construction of historical money stock estimates. This volume also devotes more than 100 pages to alternative approaches to the definition of money.

The Federal Reserve Rulletin and the Board of Governors' Annual Report generally document and explain definitional changes in the monetary aggre- gates. Banking and Monetary Statistics, 1941-1970, published by the Board of Governors, includes a detailed discussion of the Fed's money stock measures.

"The Monetary Base-Explanation and Analytical Use," by Leonall C. Anderson and Jerry L. Jordan, in the August 1968 Federal Reserve Bank of St. Louis Review, explains the construction of the St. Louis version of the monetary base and points out why that concept is of importance to monetary economists. The Board of Governors' H.3 release gives a complete definition of the Board's monetary base in its footnotes. Carl M. Gamb's "Federal Reserve Intermediate Targets: Money or the Monetary Base?" in the January 1980 Federal Reserve Bank of Kansas City Economic Review, discusses the pros and cons of use of the monetary base in monetary control and provides a good review of the Board's and St. Louis' construction of the base.

\section{References}

Anderson, Leonall C., and Jerry L. Jordan. "The Monetary Base-Explanation and Analytical Use." Federal Reserve Bank of St. Louis Review 50 (August 1968): 7-11.

Bernanke, Ben S., and Alan S. Blinder. "Credit, Money, and Aggregate Demand." American Economic Review 78 (May 1988): $435-39$.

Board of Governors of the Federal Reserve System. "A Proposal for Redefining the Monetary Aggregates." Federal Reserve Bulletin 65 (January 1979): 13-42.

Washington, 1976

Bunking and Monetury Statistics, 1941-1970. Washington, 1976

"Implementing Monctary Policy." Federal Reserve Bulletin 74 (July 1988): 419-29.

"Improving the Monetary Aggregates." Report of the Advisory Committee on Monetary Statistics. June 1976.

Monetary Aggregates and Money Marke Conditions in Open Market Policy." Federal Reserve Bulletin 57 (February 1971): 79-95.

_Monetary Policy Report to the Congress." Federal Reserve Bulletin 74 (August 1988): 517-33.

"Monetary Policy Report to the Congress." Federal Reserve Bulletin 75 (March 1989), forthcoming.

"Money Stock Revisions." (Annual historical Reserve System "Mederal Reserve System release H.6, "Money Stock, Liquid Assets, and Debt Measures"). March 1988.

"New Monetary and Banking Statistics." Federal Reserve Bulletin 30 (February 1944): 134.
- "Notes to Tablc 1.21." Federal Reserve Bulletin 72 (November 1986): A14.

"Reserves of Depository Institutions." (Annual historical supplement to the Board of Governors of the Federal Reserve System release H.3, "Aggregate Reserves of Depository Institutions and the Monetary Base"). June 1988.

69th Annual Report, 1982. Washington: Board of Governors, 1983.

The Federal Reserve System: Purposes \& Functions. 7th ed. Washington: Board of Governors, 1984.

Broaddus, Alfred. "Aggregating the Monetary Aggregates: Concepts and Issues." Federal Reserve Bank of Richmond Economic Reviere 61 (November/December 1975): 3-12.

Bank of Richmond, 1988.

Broaddus, Alfred, and Marvin Goodfriend. "Base Drift and the Longer Run Growth of M1: Experience from a Decade of Monetary Targeting." Federal Reserve Bank of Richmond Economic Reviero 70 (November/December 1984): 3-14.

Burger, Albert E. "Alternative Measures of the Monetary Base." Federal Reserve Bank of St. Louis Review 61 (June 1979): 3-8.

The Money Supply Process. Belmont, California: Wadsworth Publishing Co., Inc., 1971.

Cook, Timothy Q. "The 1983 M1 Seasonal Factor Revisions: An Illustration of Problems That May Arise in Using Seasonally Adjusted Data for Policy Purposes." Federal Reserve Bank of Richmond Economic Review 70 (March/April 1984): 22-33. 
Cook, Timothy Q., and Timothy D. Rowe, eds. Instruments of the Money Market, 6th ed. Richmond: Federal Reserve Bank of Richmond, 1986.

Duprey, James $\mathrm{N}$. "How the Fed Defines and Measures Money." Federal Reserve Bank of Minneapolis Quarterly Review (Spring-Summer 1982), pp. 10-19.

Federal Reserve Bank of St. Louis. "Monetary Trends." Various dates.

"U.S. Financial Data." Various dates.

Friedman, Benjamin M. "Monetary Policy Without Quantity Variables." American Economic Revieso 78 (May 1988): 440-45.

Friedman, Milton. The Optimum Quantity of Money and Other Essays. Chicago: Aldine Publishing Company, 1969.

Friedman, Milton, and Anna Jacobson Schwartz. A Monetary History of the United States, 1867-1960. Princeton, N.J.: Princeton University Press, 1963.

Monetary Statistics of the United States, Estimates, Sources, Methods. New York: National Bureau of Economic Research, 1970.

Gambs, Carl M. "Federal Reserve Intermediate Targets: Money or the Monetary Base?" Federal Reserve Bank of Kansas City Economic Reviero 65 (January 1980): 3-15.

Glassman, Cynthia A. "Data Sources Used in Constructing the U.S. Monetary Aggregates." Paper presented at 21 st Meeting of Technicians of Central Banks of the American Continent. Washington: Board of Governors of the Federal Reserve System, Division of Research and Statistics, Financial Reports Section, 1984.

Greenspan, Alan. "Statement before the Committee on Banking, Finance and Urban Affairs, U.S. House of Representatives, February 21, 1989." Federal Reserve Bulletin 75 (April 1989), forthcoming.

Hein, Scott E., and Mack Ott. "Seasonally Adjusting Money: Procedures, Problems, Proposals." Federal Reserve Bank of St. Louis Review 65 (November 1983): 16-24.

Hetzel, Robert L., and Yash P. Mehra. "The Behavior of Money Demand in the 1980s." Federal Reserve Bank of Richmond, June 1988. Photocopy.
Humphrey, Thomas M. "The Theory of Multiple Expansion of Deposits: What It Is and Whence It Came." Federal Reserve Bank of Richmond Economic Reviesw 73 (March/April 1987): 3-11.

Lawler, Thomas A. "Seasonal Adjustment of the Money Stock: Problems and Policy Implications." Federal Reserve Bank of Richmond Economic Review 63 (Novemberl December 1977): 19-27.

Lindsey, David E., and Henry C. Wallich. "Monetary Policy." In The New Palgrave, A Dictionary of Economics, edited by John Eatwell, Murray Milgate, and Peter Newman, vol. 3. London: The MacMillan Press Limited, 1987, pp. 508-15.

Loeys, Jan G. "Market Views of Monetary Policy and Reactions to M1 Announcements." Federal Reserve Bank of Philadelphia Business Review (March/April 1984), pp. 9-17.

Mehra, Yash P. "The Forecast Performance of Alternative Models of Inflation." Federal Reserve Bank of Richmond Economic Reviere 74 (September/October 1988): 10-18.

McCarthy, F. Ward, Jr. "Basics of Fed Watching." In The Handbook of Treasury Securities, edited by Frank J. Fabozzi. Chicago: Probus, 1987.

Reichenstein, William, and J. Waiter Elliott. "A Comparison of Models of Long-Term Inflationary Expectations." Joumal of Monetary Economics 19 (May 1987): 405-25.

Simpson, Thomas D. "The Redefined Monetary Aggregates." Federal Reserve Bulletin (February 1980): 97-114.

Stone, Courtenay C., and Jeffrey B. C. Olson. "Are the Preliminary Week-to-Week Fluctuations in M1 Biased?" Federal Reserve Bank of St. Louis Review 63 (December 1978): $13-20$.

Taylor, Herb. "What Has Happened to M1?" Federal Reserve Bank of Philadelphia Business Review (September/October 1986), pp. 3-14.

Walter, John R. "How to. Interpret the Weekly Federal Reserve Data." In The Financial Analyst's Handbook, 2nd. ed., edited by Sumner N. Levine. Homewood, Illinois: Dow Jones-Irwin, 1988. 